IZA DP No. 10047

Intergenerational Mobility in Income and

Economic Status in Ethiopia

Getinet Astatike Haile

July 2016 


\title{
Intergenerational Mobility in Income and Economic Status in Ethiopia
}

\author{
Getinet Astatike Haile \\ University Nottingham \\ and IZA
}
Discussion Paper No. 10047
July 2016

\author{
IZA \\ P.O. Box 7240 \\ 53072 Bonn \\ Germany \\ Phone: +49-228-3894-0 \\ Fax: +49-228-3894-180 \\ E-mail: iza@iza.org
}

\begin{abstract}
Any opinions expressed here are those of the author(s) and not those of IZA. Research published in this series may include views on policy, but the institute itself takes no institutional policy positions. The IZA research network is committed to the IZA Guiding Principles of Research Integrity.

The Institute for the Study of Labor (IZA) in Bonn is a local and virtual international research center and a place of communication between science, politics and business. IZA is an independent nonprofit organization supported by Deutsche Post Foundation. The center is associated with the University of Bonn and offers a stimulating research environment through its international network, workshops and conferences, data service, project support, research visits and doctoral program. IZA engages in (i) original and internationally competitive research in all fields of labor economics, (ii) development of policy concepts, and (iii) dissemination of research results and concepts to the interested public.
\end{abstract}

IZA Discussion Papers often represent preliminary work and are circulated to encourage discussion. Citation of such a paper should account for its provisional character. A revised version may be available directly from the author. 


\section{ABSTRACT \\ Intergenerational Mobility in Income and Economic Status in Ethiopia*}

Using data from two comprehensive national labour force surveys conducted in 2005 and 2013, this paper examines the extent of intergenerational mobility in Ethiopia using monetary and non-monetary measures. Quantile regression and OLS based results suggest there is moderate level of "stickiness" in income mobility across generations. Sons are found to be more mobile than daughters both in monetary and non-monetary terms, although the mobility gap appears to have narrowed recently. There is virtually no evidence on intergenerational mobility in the context of low income countries in general and Sub-Saharan Africa in particular. The paper thus provides valuable insights into issues of intergenerational mobility in a low income country setting. The mixed approach used addresses possible measurement error in income, as well as offering a broader scope in examining intergenerational mobility.

JEL Classification: J62, D31

Keywords: intergenerational mobility, income, education, occupation, Ethiopia

Corresponding author:

Getinet Astatike Haile

Division of Industrial Economics

Nottingham University Business School

South Building, Jubilee Campus

Wollaton Road

Nottingham, NG8 1BB

United Kingdom

E-mail: getinet.haile@nottingham.ac.uk

\footnotetext{
* The author would like to thank the Central Statistical Agency (CSA) of Ethiopia for making the data used in this paper available. The usual disclaimer applies.
} 


\section{Introduction}

Intergenerational mobility is said to happen when children 'occupy different positions in their generation's distribution of economic status than did their parents in their generation's distribution' (Dearden et al. 1997, p.47). The question of how parental or family background influences children's lifetime economic status has been the subject of considerable research particularly since the seminal work of Becker and Tomes (1986). ${ }^{1}$ The central hypothesis of this literature lies on parental altruism towards the welfare of their children generally and investments in their human capital, which shape the fortunes of children beyond the heredity of cognitive ability and other genetic traits.

The level of intergenerational mobility in a society is thought to reflect the degree of equality in economic opportunities in the society. Although inequality in income and economic status is a common feature across countries, the rate of inequality in lowincome countries is reported to be much higher than that in high-income ones (UNDP 2013). Understanding the drivers of inequality in income and economic status is vital to address issues of inequality. Examining the distributions of income and economic status between successive generations plays an important role in this regard. This paper aims to shed some light on intergenerational mobility in income and economic status in Ethiopia and investigates the extent to which inequities in income and economic status are transmitted across generations.

The bulk of the literature on intergenerational mobility relies on income or earnings to measure mobility. This is justified on the ground that such a measure provides a simple metric in examining mobility through the correlation between the income levels of two successive generations. In cross-sectional data of the sort used in this paper, this is often realised through a linear regression of children's income on the income of their parents, both log-transformed, to yield a measure of intergenerational mobility. An alternative to using income or earnings to measure economic status is to use non-monetary measures, such as occupational status or educational attainment (See, for example, Carmichael

\footnotetext{
${ }^{1}$ Some of the recent studies include Black et al. (2015), Blandan and Macmillan (2014), Corak (2013), Black and Devereux (2010), Aaronson and Mazumder (2008), Currie (2008), Jenkins and Siedler (2007), Ferreira and Veloso (2006), Blandan (2005), Dustmann (2005), Nguyen et al. (2005).
} 
2000; Johnson, 2002; Erikson and Goldthorpe 2002). The non-monetary approach may offer a broader account of intergenerational mobility as it depicts mobility in both economic and social status. Investigating intergenerational mobility on a range of different measures, such as educational attainment and occupational status in addition to income, may thus provide a more comprehensive picture of intergenerational transmission in economic status. In fact, some, for example Goldberger (1989), warn that exclusive focus on monetary measures such as income or earnings may 'understate the influence of family background on inequality' (p. 513). On the other hand, focusing entirely on non-monetary measures runs the risk of misclassification and hence of obtaining biased estimates of intergenerational mobility.

Taking these issues into account, this paper combines the monetary and non-monetary approaches to examine the level of intergenerational mobility in income and economic status among a sample of young adults between 25 and 35 years of age and their parents in Ethiopia. To this end, the paper uses data from two comprehensive and nationally representative labour force surveys conducted in 2005 and 2013. It also examines if systematic differences in mobility exists between sons and daughters. Due to the challenges posed by the labour market histories of women, which are often interrupted for family and child care reasons, most previous studies have focused almost exclusively on the intergenerational linkages between fathers and sons. ${ }^{2}$ This paper follows the same approach and relies on fathers' income; but it examines intergenerational mobility between both fathers and sons and fathers and daughters.

Although there has been extensive research on intergenerational mobility in economic status, the focus of the literature has almost exclusively been on advanced economies. ${ }^{3}$ In the context of Sub-Saharan Africa, there is in fact virtually no evidence on intergenerational mobility to date. This paper thus has the potential to provide important insights into intergenerational mobility generally and potential differences between sons

\footnotetext{
${ }^{2}$ Hotchkiss and Pitts (2007), Phipps et al. (2001), Blau and Kahn (2000) dwell on such interruptions rigorously. In the low income country context considered here, the expectation is that interruptions of this nature are likely to have far more serious repercussions given weak labour market institutions, which may entail longer or permanent interruptions. Importantly, this compounds the measurement error problems for mothers' income.

${ }^{3}$ The few exceptions to this include Piraino (2014), Brunori et al. (2013) and Thomas (1996) on South Africa; Gong et al. (2012) on China; Ferreira et al. (2011) on Turkey; Ferreira and Gignoux (2011) on Latin America; Ferreira and Veloso (2006) and Dunn (2007) on Brazil, and Blinder and Woodruff (2002) on Mexico.
} 
and daughters in the context of a low income country, which may be of considerable interest for researchers and policy makers alike. The paper is organized as follows. Section 2 describes the LFS data used, providing some background information on income levels as well as the educational and occupational statuses of parents and adult children in the Ethiopian dataset. Section 3 previews the empirical framework adopted to estimate the intergenerational mobility in income, educational attainment and occupational status. Section 4 discusses the results of the statistical analysis and section 5 concludes the paper.

\section{Data and variables}

The data used in this paper come from the 2005 and 2013 Labour Force Surveys of Ethiopia. The surveys constitute the most recent two sweeps of the three nationally representative and comprehensive household surveys collected by the Central Statistical Agency (CSA) of Ethiopia, which began in 1999. ${ }^{4}$ The surveys gather extensive labour market information with the aim of monitoring the economic and social situation of the economically active population in the country. As detailed in Kolev and Robles (2010) the surveys gathered extensive individual information on demographic characteristics such as age and gender; household composition and individual respondents relationship to the head and spouse of the household; educational qualification; employment status; job characteristics including earnings, among others. This paper uses data on young adults (children) between 25 and 35 years of age, inclusive, and their fathers to examine intergenerational mobility.

The 2005 and 2013 LFSs monitored 230,680 and 240,660 individuals in total, respectively, nationally. Of these, 114,827 and 120,709 individuals were children of either both or one of the household head and their spouse. The important parts of the data setup involved: ( $i$ ) identifying the father-child pair(s) in each household and (ii) generating new variables that record the relevant data on fathers' education, employment and earnings across all children between 25 and 35 years of age within each household

\footnotetext{
${ }^{4}$ http://www.csa.gov.et/. The 1999 LFS did not gather data on earnings however, which is the reason for excluding data from the survey.
} 
monitored by the two LFSs. In both waves, fathers were identified based on whether a respondent was male and had a head or spouse status within the household. Once the relevant information on fathers has been copied across to each young adult in each of the households surveyed, only the young adults have been retained for the analyses conducted. This has yielded 5,493 and 7,759 young adults in 2005 and 2013 respectively. All retained young adults have information on their and their fathers' educational and occupational status and thus form the basis for the empirical analysis examining intergenerational mobility in educational and occupational mobility. The top panel of Table A1 in the Appendix provides descriptive statistics on demographic characteristics, educational qualification, occupation status, household and parental size as well as geographic region of the retained sample of young adults, disaggregated by survey year. The bottom panel of Table A1 provides descriptive statistics on the earnings information of young adult children and their father, which has been symmetrically winsorized at $2 \% .^{5}$ The earnings data come from individual responses to the question 'what was the total amount paid in your main occupation during the last month?' The Table shows a much reduced sample size of father-child pairs with valid information on earnings, which is caused largely by missing data on fathers' earnings.

\section{Framework of analysis}

The paper adopts two main empirical strategies to examine intergenerational mobility in income and economic status.

\subsection{Intergenerational Income Mobility}

The traditional framework for measuring intergenerational income mobility is based on a regression-to-the-mean model, involving OLS regression of the log of children's income on the log of their parent's (often father's) income. ${ }^{6}$ However, parental "permanent"

\footnotetext{
${ }^{5}$ Symmetric winsorization has been chosen instead of trimming to minimise loss in observations on father-child pairs with valid earnings information. See Lien and Balakrishnan (2005) for details on trimming versus winsorization.

${ }^{6}$ The typical model estimated takes the form $y_{i}^{c}=\alpha+\beta y_{i}^{p}+\varepsilon_{i}$ or $y_{i, t}=\alpha+\beta y_{i, t-1}+\varepsilon_{i}$ where $y$ stands for 'permanent' income and superscripts (subscripts) c and $\mathrm{p}(t$ and $t-1)$ represent child(ren) and their parent(s), respectively, in household $i$.
} 
income is often unobserved. Instead, researchers rely on some transitory income in one or several periods. This has potential measurement error problem, which biases the estimated income elasticity downwards (see for e.g. Zimmerman, 1992; Dearden et al, 1997; Naga, 2002, Black and Devereux 2011). ${ }^{7}$ Several approaches have been suggested to overcome the measurement error problem, each with its own potential limitations. Solon (1992) and Zimmerman (1992) suggest the use of "long-run" average parental income $^{8}$ while others (Behrman and Taubman 1990; Mulligan 1999) suggest a variant of this approach where the "long-run" average of child's income is regressed on the "longrun" average of parental income. Naga (2002) argues that the latter approach is more efficient than using only the "long-run" average of parental income. As noted by Mazumder (2001), however, most of the applied work in the literature relies on short time-series due to data limitations. This is likely to lead to biased estimates caused by transitory income shocks, which may leads to high serial correlation in the income variable. ${ }^{9}$ Solon (1992) makes another suggestion involving the use of instrumental variables technique with parental education serving as an instrument. This approach may yield an upward-inconsistent estimate; since the child's long-term economic status or "permanent" income is determined not only by parental income but also by their level of education. However, he argues that the IV approach yields an upper bound of the true intergenerational income mobility. Dearden et al. (1997) and Naga (2002) use predicted parental income as a proxy for parental "permanent" income. They argue that although "permanent" income may not be observed, a model of the determination of parents' income is known to the researcher, which can be used to estimate parental "permanent" income.

The measurement error problem alluded to in the preceding paragraph is likely to be more of a concern in the context of a low income country such as Ethiopia for two main reasons. First, time-series data on income are unavailable in such countries generally. Even where available, however, they are bound to be much shorter than what have been

\footnotetext{
${ }^{7}$ Income is often measured for a particular year, which is too short since the transitory variance of measured income may lead to bias in $\beta$.

${ }^{8}$ This is done by regressing child's income on a time-series average of parents' income. The inconsistency of this estimator diminishes as the length of the time-series increases (Solon 1992).

${ }^{9}$ Mazumder (2001) also recommends the use of income instead of earnings, as the former is likely to be a less noisy measure of economic status than earnings.
} 
used in the literature in the context of developed countries, thus ruling out the notion of having long-run average or permanent income information. Secondly, it is safe to assume that transitory income shocks are more of a concern in the context of low income countries than in their developed counterparts, thus making the problem of high serial correlation noted earlier even more of an issue

Taking such concerns into account, this paper implements the approach suggested by Dearden et al. (1997) and Naga (2002); and uses predicted parental income as a proxy for "permanent" income, thus estimating the following model:

$$
y_{i, j}^{c}=\alpha^{c}+\beta \hat{y}_{j}^{p}+\varepsilon_{i}^{c}
$$

where, $y$ stands for actual reported income; $\hat{y}$ is predicted income proxying 'permanent' income; superscripts $c$ and $p$ index children and their parent(s), respectively; $i$ and $j$ index children and households. ${ }^{10}$ The estimated coefficient $\beta$ yields the intergenerational elasticity, while $(1-\beta)$ gives a measure of the intergenerational mobility. ${ }^{11}$ The two extreme values for the coefficient are: $\beta=0$, which signifies complete intergenerational mobility (regression to the mean) with no correlation between children's and parents' income, and $\beta=1$, which suggests complete intergenerational immobility where, ruling out $\varepsilon_{i}$, children's income is completely determined by their parents'.

Notwithstanding the measurement issues discussed earlier, equation (1) does not handle possible nonlinearities in the incomes of children and their parents. To address this, two approaches have been implemented. First, transition matrix of the quantiles of children's and parental income are used to yield: $(i)$ the proportion of all children with earnings quantiles below the earnings quantiles of their parent (i.e., the sum of the proportions below the main diagonal of the transition matrix), (ii) the proportion of all children with

\footnotetext{
${ }^{10}$ In the context of developing countries in particular, there is a real possibility that there are more than one children per household, which the empirical analysis carried out in this paper takes into account.

${ }^{11}$ If $y_{i, j}^{c}$ and $y_{j}^{p}$ are measured in logarithms, the coefficient $\beta$ corresponds to the elasticity of the child's income with respect to the parents' income. In case of equal variances across generations, $\beta$ represents the intergenerational correlation coefficient. In case of differing variances, the correlation coefficient can be estimated as $\rho=\beta\left(\sigma_{j}^{p} / \sigma_{i, j}^{c}\right)$ (Osterberg 2000, Bowles and Gintis 2002, Black and Devereux 2011).
} 
earnings quantiles same as the earnings quantiles of their parent (i.e., the sum of proportions on the main diagonal) and (iii) the proportion of all children with earnings quantiles above the earnings quantiles of their parent (i.e. the sum of the proportions above the main diagonal). These proportions and differences in them between sons and daughters are used to examine intergenerational mobility in earnings. Secondly, a quantile regression procedure, which estimates quantiles of children's income conditional on parental income, has also been implemented in this paper. Quantile regression rules out the implicit assumption in equation (1) that the effect of parental income does not change across the entire distribution of children's income. Suppose that $Q_{\theta}\left(y_{i, j}^{c} \mid \hat{y}_{j}^{p}\right)$ denotes the $\theta^{\text {th }}$ quantile of the income of a young adult in family $j$ conditional on their parental income. The $\theta^{\text {th }}$ quantile of the conditional distribution of $y_{i, j}^{c}$ given $\hat{y}_{j}^{p}$ is then defined as $Q_{\theta}\left(y_{i, j}^{c} \mid \hat{y}_{j}^{p}\right)=\beta(\theta) \hat{y}_{j}^{p}, \theta \in(0,1)$. Quantile regression in this case involves minimization of the following objective function (Koenker and Bassett 1978):

$$
\underset{\beta_{\theta} \in R^{k}}{\operatorname{Min}} Q\left(\beta_{\theta}\right)=\sum_{i \in\left\{i: y_{i, j}^{c} \geq \beta_{\theta} \hat{y}_{j}^{p}\right\}} \theta\left|y_{i, j}^{c}-\beta_{\theta} \hat{y}_{j}^{p}\right|+\sum_{i \in\left\{i: y_{i, j}^{c}<\beta_{\theta} \hat{y}_{j}^{p}\right\}}(1-\theta)\left|y_{i, j}^{c}-\beta_{\theta} \hat{y}_{j}^{p}\right|
$$

where, as before, $y_{i, j}^{c}$ is the income of young adult(s) in family $j, \hat{y}_{j}^{p}$ is parental income, $\beta_{\theta}$ represents the coefficients of interest, $\theta$ is the particular quantile of interest. ${ }^{12}$ The estimated $\beta_{\theta}$ parameters may differ depending on the particular quantile being estimated. This allows the analysis of: $(i)$ differential effects of parental income on children's income across the income distribution of the young adults in general and (ii) differential effects of parental income between different groups of young adults, specifically between sons and daughters, at different quantiles of the conditional distribution of children's income.

\footnotetext{
12 Equation (2) shows that the minimization problem attaches asymmetric penalties of $(1-\theta)$ and $\theta$ for overprediction and underprediction, respectively, and is solved using linear programming methods (Buchinsky, 1998).
} 


\subsection{Intergenerational Mobility in Economic Status}

To examine intergenerational mobility in non-monetary economic status, the paper follows Goldberger (1989) and Nguyen et al. (2005), which involves comparing the occupational and educational status of children and that of their parents'. The nonmonetary indicators of economic status are likely to provide less noisy measures of longterm economic status than income as they are less sensitive to transitory shocks (Nickell, 1982; Ermisch and Francesconi, 2002). Measurement errors are also much less of an issue with educational and occupational status than earnings (Black and Devereux 2011). Moreover, educational attainment and occupational status are highly correlated with income (Nickell, 1982; Johnson, 2002). The nonmonetary measures of intergenerational mobility are thus likely to provide suitable complementary measures to the income measures of mobility discussed earlier.

The educational attainment rankings of children and their father used in the empirical analysis are as follows: ( $i)$ no education or can't read and write $(y=0)$; (ii) grades 1 to 6 $(y=1)$; (iii) grades 7 to $10(y=2)$, and (iv) grade 11 and higher $(y=3)$. On the other hand, the occupational status rankings are: (i) no occupation $(y=0)$; (ii) elementary occupations $(y=1)$; (iii) skilled agriculture and forestry $(y=2)$; (iv) services and sales $(y$ $=3) ;(v)$ machine operator and crafts $(y=4) ;(v i)$ managerial and professional $(y=5){ }^{13}$

These rankings are analysed in two ways. First, similar to the approach used in the income mobility analysis, transition matrices involving the educational and occupational status of children and their parents have been used to generate: $(i)$ the proportion of sons and daughters with an educational attainment (or occupational status) level that is lower than that achieved by their parent; (ii) the proportion of sons and daughters with the same educational attainment (or occupational status) as their parent's, and (iii) the proportion of sons and daughters with an educational attainment (or occupational status) higher than that achieved by their parents. Once again, these proportions and differences between

\footnotetext{
${ }^{13}$ Unlike the income measure, here the highest status of either the father or the mother has been taken as the highest estatusIt is important to note, however, that the ordering of these categories does have some arbitrariness; and one cannot completely rule out some overlaps/misclassifications as pointed out in Erikson and Goldthorpe (2002).
} 
sons and daughters allow examining intergenerational mobility in non-monetary economic status.

Secondly, ordered probit model is used to estimate the influence of parental educational or occupational status on the educational attainment or occupational status of their sons and daughters. This model based analysis has the advantage of allowing other familyrelated factors, such as family structure and the number of siblings, to be taken into account in examining intergenerational mobility in non-monetary economic status; and the role played by family background factors in this respect. There is some evidence highlighting the importance of family background factors in the process of intergenerational mobility. For example, a two-parent family may have more resources and may, consequently, be in a better position to invest more in their children's education than a single parent family. Also, it may be essential that the child quality-quantity tradeoff (Becker 1991; Hanusheck 1992) is taken into account. Large family/sibling size may lead to resources being spread more thinly within the family particularly where siblings, or at least some of them, are not fully engaged economically. This is likely to adversely impact the educational and occupational status of children in large families with many siblings.

The ordered probit model used to examine intergenerational mobility in non-monetary economic status has the following general format:

$$
y_{i, j}^{c}=\alpha^{c}+\beta y_{j}^{p}+\mathbf{x}_{i, j}^{\prime} \varphi+\mathbf{z}_{j}^{\prime} \gamma+\varepsilon_{i}^{c}
$$

where, this time $y$ represents ordinally measured educational and occupational statuses of young adults and their parents in household $j$ and $\mathbf{x}_{i j}$ is the vector of characteristics of the young adult $i$ in household $j$, and $\mathbf{z}_{j}$ represents the vector of family characteristics.

\section{Results and discussion}

\subsection{Intergenerational mobility in income}


Table 1 reports the unconditional probabilities obtained from transition matrices involving quantiles of children's and their father's earnings, which reveals that slightly more than $40 \%$ of children being in lower income quantiles than their father's whether viewed in the combined 2005 and 2013 sample or separately by year. Only 19\% of children are found to be in higher income quantiles in the combined sample, with a $24 \%$ and 17\% split between 2005 and 2013, respectively. The Table also shows an 8 percentage point decline in the proportion of children found in higher income quantile than their father between 2005 and 2013.

Table 1: Child-father Income Quantiles and their Distribution, LFS 2005 \& LFS 2013 (\%)

\begin{tabular}{|c|c|c|c|c|}
\hline & $\begin{array}{l}\text { Sons \& Daughters } \\
\text { (1) }\end{array}$ & $\begin{array}{l}\text { Son } \\
(2) \\
\end{array}$ & $\begin{array}{l}\text { Daughter } \\
(3)\end{array}$ & $\begin{array}{l}\text { Diff. } \\
(2-3)\end{array}$ \\
\hline \multicolumn{5}{|l|}{ Combined 2005 \& 2013 sample $(N=1186)$} \\
\hline$\%$ in lower income quantile than father & 42.5 & 36.1 & 52.9 & $-16.8 * * *$ \\
\hline$\%$ in the same income quantile as father & 38.4 & 40.0 & 35.7 & 4.3 \\
\hline$\%$ in higher income quantile than father & 19.1 & 23.9 & 11.5 & $12.5 * * *$ \\
\hline Total & 100 & 100 & 100 & 100 \\
\hline \multicolumn{5}{|l|}{2005 sample $(N=397)$} \\
\hline$\%$ in lower income quantile than father & 40.1 & 32.7 & 53.1 & $-20.5 * * *$ \\
\hline$\%$ in the same income quantile as father & 35.5 & 38.6 & 30.1 & $8.5^{*}$ \\
\hline$\%$ in higher income quantile than father & 24.4 & 28.7 & 16.8 & $12.0 * * *$ \\
\hline Total & 100 & 100 & 100 & 100 \\
\hline \multicolumn{5}{|l|}{2013 sample $(N=789)$} \\
\hline$\%$ in lower income quantile than father & 43.7 & 37.9 & 52.7 & $-14.9 * * *$ \\
\hline$\%$ in the same income quantile as father & 39.8 & 40.8 & 38.3 & 2.5 \\
\hline$\%$ in higher income quantile than father & 16.5 & 21.3 & 9.0 & $12.3 * * *$ \\
\hline Total & 100 & 100 & 100 & \\
\hline
\end{tabular}

$* * * \mathrm{p}<0.01, * * \mathrm{p}<0.05, * \mathrm{p}<0.1$

Authors own computation based on Ethiopian LFS 2005 and 2013.

The gender differentials in the unconditional probabilities reveal that compared with sons, daughters are less (more) likely to be in higher (less) income quantiles than their father, differences that are found to be statistically significant. Between 2005 and 2013, the proportion of sons in lower income quantiles than their father has increased and that of daughters remained stable, while a similar proportionate decline has been observed for sons and daughters who were in the same income quantile as their father's. On the other hand, the proportion of sons and daughters who were in the same income quantile as their father's has increased between 2005 and 2013, more so for daughters. 
Table 2 reports OLS and Quantile regression results on intergenerational income mobility, which use predicted income proxying parental 'permanent' income. ${ }^{14}$ The first column reports results from OLS while the remaining columns report results from quantile regression. ${ }^{15}$ The estimated elasticities from OLS indicate that the correlation between father's and children's income stood at $43 \%$ in 2005 and declined to $37 \%$ in 2013, thus suggesting increased income mobility over the period. The elasticities from the quantile regression reveal that the conditional mean regression masks some variations in mobility both within and across the two periods. The combined son and daughter sample based estimates reveal that mobility increased across the quantiles in 2005, with the exception of the $25^{\text {th }}$ quantile. In 2013, on the other hand, mobility increased only up to and including the median quantile. The increased income mobility in 2013 the OLS estimates revealed therefore appear to be driven by the marked increase in mobility at the median quantile. On the other hand, there is a decline in mobility particularly at the top income quantile. Figure 1 below depicts plots of the estimated elasticities from quantile regression for 2005 and 2013 for the combined sample.

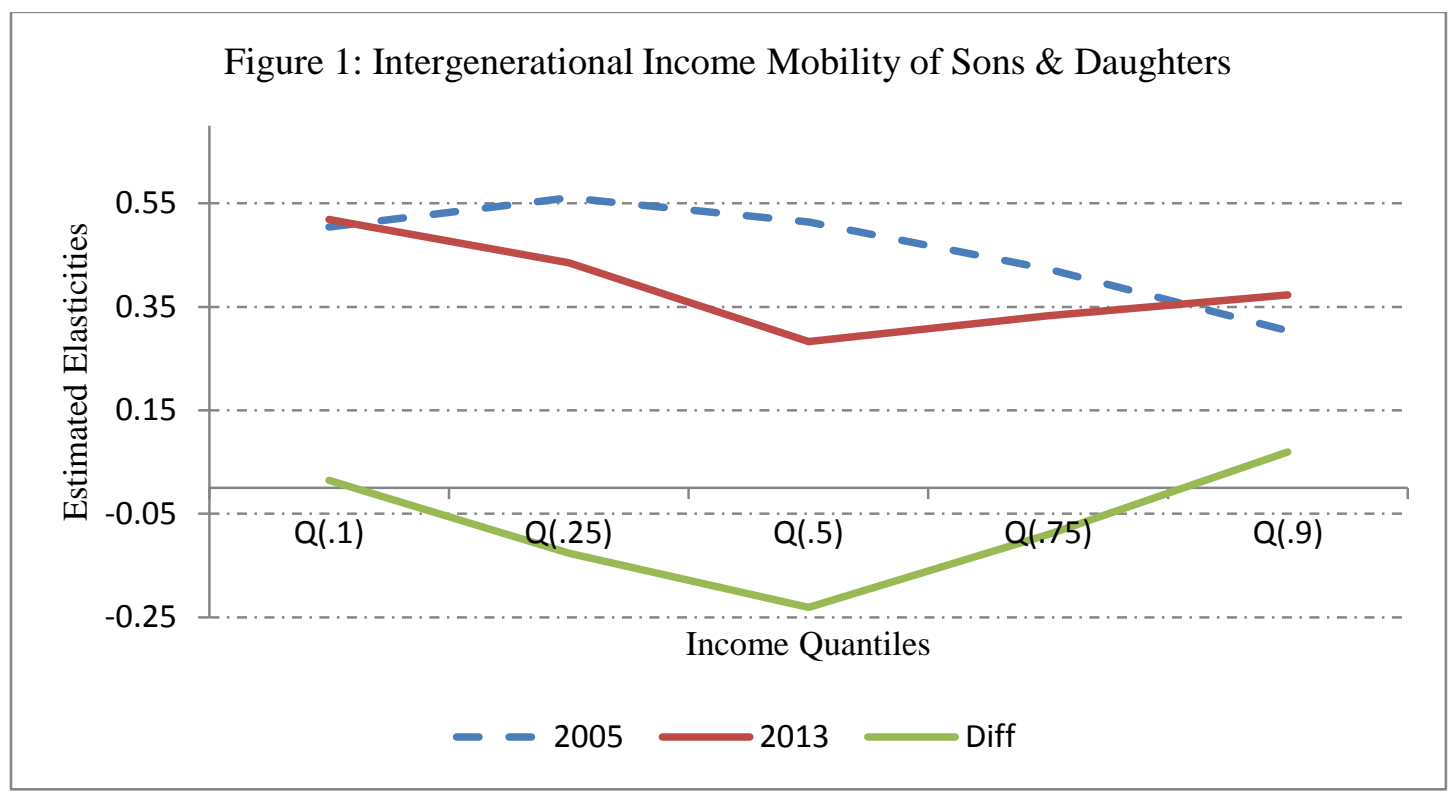

\footnotetext{
14 The estimation results predicting parental income are reported in Appendix Table A2. The parental income equation controls for the age of the father (and age squared), household size, level of education, detailed occupational and industrial categories as well as region; and the results are very much in line with theoretical predictions and what one would expected from a similar equation.

${ }^{15}$ It is worth pointing out that the income measures used are all in local currency and not adjusted for inflation even though this should not affect the observed gender differential.
} 
The contrast in the gender differential in income mobility is noteworthy. Results from OLS indicate that in 2005 sons, with an estimated income elasticity of 39\%, were significantly more mobile than daughters whose income elasticity was found to be $56 \%$. However, OLS estimates suggest that daughters have gained some ground in narrowing the gap in income mobility in 2013, when their income elasticity is found to be $44 \%$ (i.e. a 12 percentage point decline) compared with sons whose income elasticity has declined by 3 percentage points only.

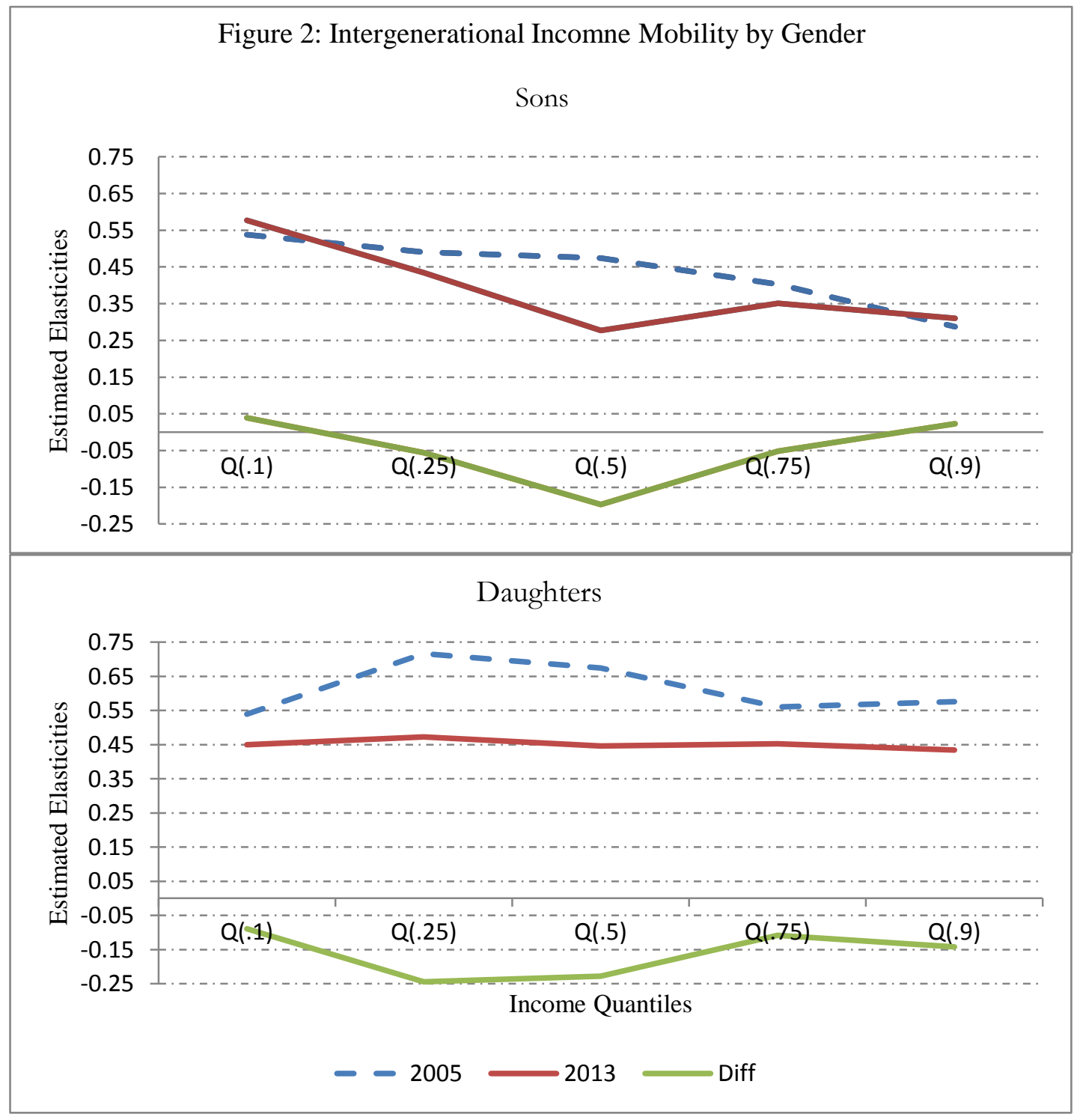


The results from quantile regression for sons and daughters reveal that son's income mobility increased linearly across the quantiles in 2005 while daughter's mobility then appeared to have an inverted-U pattern reaching its lowest level at the $25^{\text {th }}$ quantile. In contrast, in 2013, daughter's mobility remained more or less stable across the quantiles while son's mobility shows some variations across the quantiles. Figure 2 depicts the mobility patterns of sons and daughters in 2005 and 2013 based on the results from quantile regression.

Overall, the estimated income elasticities suggest that: firstly, being below $50 \%$ in most cases, they suggest that incomes are less sticky between generations in Ethiopia generally compared with similar evidence elsewhere. Secondly, the estimated elasticities are smaller for sons for the most part, compared with that of daughters, suggesting that there is a gender gap in income mobility in favour of sons. Thirdly, daughters appear to have gained some ground in income mobility terms between 2005 and 2013, albeit this being mostly at the median and lower quantiles of the income distribution, thus with the resulting narrowing of the gender gap in income mobility between 2005 and 2013.

Table 2: Intergenerational Income Mobility of Sons and Daughters, OLS \& Quantile Regression.

\begin{tabular}{|c|c|c|c|c|c|c|}
\hline & OLS & $\mathrm{Q}(.1)$ & $\mathrm{Q}(.25)$ & $Q(.5)$ & $\mathrm{Q}(.75)$ & $\mathrm{Q}(.9)$ \\
\hline \multicolumn{7}{|l|}{ Sons \& Daughters, 2005} \\
\hline \multirow[t]{2}{*}{ Father's income } & $0.432 * * *$ & $0.504 * * *$ & $0.561 * * *$ & $0.514 * * *$ & $0.423 * * *$ & $0.304 * * *$ \\
\hline & $(0.073)$ & $(0.183)$ & $(0.138)$ & $(0.069)$ & $(0.079)$ & $(0.102)$ \\
\hline $\mathrm{N}$ & 397 & 397 & 397 & 397 & 397 & 397 \\
\hline \multicolumn{7}{|l|}{ Sons, 2005} \\
\hline \multirow[t]{2}{*}{ Father's income } & $0.389 * * *$ & $0.538 * *$ & $0.490 * * *$ & $0.474 * * *$ & $0.403 * * *$ & $0.287 * *$ \\
\hline & $(0.094)$ & $(0.235)$ & $(0.174)$ & $(0.113)$ & $(0.098)$ & $(0.125)$ \\
\hline $\mathrm{N}$ & 254 & 254 & 254 & 254 & 254 & 254 \\
\hline \multicolumn{7}{|l|}{ Daughters, 2005} \\
\hline \multirow[t]{2}{*}{ Father's income } & $0.559 * * *$ & $0.539 * *$ & $0.716 * * *$ & $0.674 * * *$ & $0.560 * * *$ & $0.576 * * *$ \\
\hline & $(0.110)$ & $(0.254)$ & $(0.228)$ & $(0.140)$ & $(0.124)$ & $(0.165)$ \\
\hline $\mathrm{N}$ & 143 & 143 & 143 & 143 & 143 & 143 \\
\hline Sons \& Daughters, 2013 & 2013 & & & & & \\
\hline \multirow{2}{*}{ Father's income } & $0.369 * * *$ & $0.519 * * *$ & $0.435 * * *$ & $0.283 * * *$ & $0.333 * * *$ & $0.373 * * *$ \\
\hline & $(0.040)$ & $(0.088)$ & $(0.072)$ & $(0.048)$ & $(0.049)$ & $(0.049)$ \\
\hline $\mathrm{N}$ & 789 & 789 & 789 & 789 & 789 & 789 \\
\hline \multicolumn{7}{|l|}{ Sons, 2013} \\
\hline \multirow[t]{2}{*}{ Father's income } & $0.357 * * *$ & $0.577 * * *$ & $0.434 * * *$ & $0.277 * * *$ & $0.351 * * *$ & $0.310 * * *$ \\
\hline & $(0.051)$ & $(0.085)$ & $(0.095)$ & $(0.067)$ & $(0.057)$ & $(0.057)$ \\
\hline $\mathrm{N}$ & 478 & 478 & 478 & 478 & 478 & 478 \\
\hline
\end{tabular}




\begin{tabular}{cllllll}
\hline \multicolumn{1}{c}{ Daughters, 2013} & & & & & & \\
Father's income & $0.436 * * *$ & $0.450 * * *$ & $0.472 * * *$ & $0.446 * * *$ & $0.452 * * *$ & $0.434 * * *$ \\
& $(0.066)$ & $(0.119)$ & $(0.121)$ & $(0.090)$ & $(0.086)$ & $(0.078)$ \\
$\mathrm{N}$ & 311 & 311 & 311 & 311 & 311 & 311 \\
\hline
\end{tabular}

Standard errors from 250 bootstrap replications in parentheses

The bootstrap replications are based on: $332 ; 225 ; 131 ; 655 ; 422$ and 288 households, respectively, for sons \& daughters, 2005; for sons, 2005; daughters, 2005; sons and daughters, 2013; sons, 2013 and daughters 2013.

$* \mathrm{p}<0.1, * * \mathrm{p}<0.05, * * * \mathrm{p}<0.01$

\subsection{Intergenerational mobility in educational and occupational status}

\subsubsection{Educational status}

Table 3 reports unconditional probabilities from a transition matrix of the educational attainment of children and their father. The combined 2005 and 2013 sample reveals that $63 \%$ of children have achieved a higher level of educational attainment than their father, while only $6 \%$ have done worse, with the balance representing those attaining the same level of education as their father. There is a statistically significant gap in intergenerational educational attainment between sons and daughters, in favour of the former. Thus, compared with daughters, sons are 9 percentage points more likely to attain higher levels of education and 4 percentage points less likely to do worse than their father. Splitting the sample by survey year provides more or less similar picture in terms of the overall child-father attainment patterns. However, there are gender differences in these between 2005 and 2013. Compared with daughters, sons were 7 (2) percentage points more (less) likely to do better (worse) educationally than their father in 2005, while in 2013 they were 11 (5) percentage points more (less) likely to do better (worse) than their father.

Table 3: Child-father Highest Educational Levels Attained (\%)

\begin{tabular}{|c|c|c|c|c|}
\hline & $\begin{array}{l}\text { Sons \& daughters } \\
\text { (1) }\end{array}$ & $\begin{array}{l}\text { Son } \\
(2)\end{array}$ & $\begin{array}{l}\text { Daughter } \\
\text { (3) }\end{array}$ & $\begin{array}{l}\text { Diff. } \\
(2-3)\end{array}$ \\
\hline \multicolumn{5}{|c|}{ Combined 2005 \& 2013 sample $(N=13252)$} \\
\hline$\%$ in a lower level than their father & 6.1 & 4.5 & 8.4 & $-4.0 * * *$ \\
\hline$\%$ in the same level as their father & 30.8 & 28.6 & 33.8 & $-5.2 * * *$ \\
\hline$\%$ in higher level than their father & 63.1 & 66.9 & 57.8 & $9.1 * * *$ \\
\hline Total & 100 & 100 & 100 & \\
\hline \multicolumn{5}{|l|}{2005 sample $(N=5493)$} \\
\hline$\%$ in a lower level than their father & 4.3 & 3.3 & 5.6 & $-2.2 * * *$ \\
\hline$\%$ in the same level as their father & 31.8 & 29.8 & 34.6 & $-4.8 * * *$ \\
\hline$\%$ in higher level than their father & 63.94 & 66.9 & 59.8 & $7.0 * * *$ \\
\hline
\end{tabular}




\begin{tabular}{|c|c|c|c|c|}
\hline Total & 100 & 100 & 100 & \\
\hline \multicolumn{5}{|l|}{2013 sample $(N=7759)$} \\
\hline$\%$ in a lower level than their father & 7.5 & 5.3 & 10.4 & $-5.1 * * *$ \\
\hline$\%$ in the same level as their father & 30.0 & 27.7 & 33.2 & $-5.4 * * *$ \\
\hline$\%$ in higher level than their father s & 62.5 & 66.9 & 56.4 & $10.6 * * *$ \\
\hline Total & 100 & 100 & 100 & \\
\hline
\end{tabular}

Conditional marginal effects from the ordered probit models estimating transition probabilities in educational status are reported in Table $4 .{ }^{16}$ The results reveal that compared with those with fathers without education, sons \& daughters with fathers who have some level of education are generally significantly more (less) likely to attain higher (lower) levels of education. Thus, for example, in 2005 young adults with fathers who attained 'grade 11 or higher' are 50 percentage points more likely to attain the same level qualification as their father; and 26 percentage points less likely to have no education, compared with the base category of parents with no education. On the other hand, young adults with fathers with 'grades 7-10' level of qualification are 39 percentage points more likely to excel their parents educationally and 35 percentage points less likely to attain lower levels of education than their father.

The estimated marginal effects suggest that the general picture relating to the child-father patterns of educational mobility remains the same in 2013, so children who have fathers with some level of education are generally found to be significantly more (less) likely to attain higher (lower) grades of education. However, the estimated marginal effects are generally lower in magnitude in 2013. Thus, focusing on the specific examples earlier, in 2013 young adults with parents who have 'grade 11 or higher' level of education are only $44 \%$ percentage points more likely to attain 'grade 11 or higher' and only 19 percentage points less likely to have no education. Also, young adults with parents who attained a 'grades 7-10' level qualification are only 22 percentage points more likely to excel their parents educationally and only 20 percentage points less likely to attain lower levels of education in 2013. It appears, therefore, that there has been a general decline in

\footnotetext{
${ }^{16}$ The full list of marginal effects corresponding to each panel of Tables 4 and Table 6 are available in an accompanying separate file of Tables.
} 
educational mobility between 2005 and 2013. Moreover, the decline in educational mobility appears to be weighted more by the decline in daughter's attainment.

Table 4: Intergenerational Mobility in Educational Attainment of Sons \& Daughters, Marginal Effects from Ordered Probit

\begin{tabular}{|c|c|c|c|c|}
\hline & No education & Grades1-6 & Grades $7-10$ & Grade11 \& higher \\
\hline \multicolumn{5}{|c|}{ Sons \& Daughters, 2005} \\
\hline \multirow[t]{2}{*}{ Grades $1-6$} & $-0.178 * * *$ & $-0.068 * * *$ & -0.000 & $0.246^{* * *}$ \\
\hline & $(0.008)$ & $(0.005)$ & $(0.003)$ & $(0.013)$ \\
\hline \multirow[t]{2}{*}{ Grades 7-10 } & $-0.233 * * *$ & $-0.114 * * *$ & $-0.044 * * *$ & $0.391 * * *$ \\
\hline & $(0.009)$ & $(0.008)$ & $(0.008)$ & $(0.022)$ \\
\hline \multirow[t]{2}{*}{ Grade11 \& higher } & $-0.260 * * *$ & $-0.146 * * *$ & $-0.093 * * *$ & $0.499 * * *$ \\
\hline & $(0.008)$ & $(0.008)$ & $(0.010)$ & $(0.021)$ \\
\hline $\mathrm{N}$ & 5493 & 5493 & 5493 & 5493 \\
\hline \multicolumn{5}{|c|}{ Sons, 2005} \\
\hline \multirow[t]{2}{*}{ Grades1-6 } & $-0.158 * * *$ & $-0.087 * * *$ & -0.004 & $0.249 * * *$ \\
\hline & $(0.010)$ & $(0.007)$ & $(0.004)$ & $(0.017)$ \\
\hline \multirow[t]{2}{*}{ Grades 7-10 } & $-0.202 * * *$ & $-0.140 * * *$ & $-0.049 * * *$ & $0.391 * * *$ \\
\hline & $(0.010)$ & $(0.011)$ & $(0.011)$ & $(0.028)$ \\
\hline \multirow[t]{2}{*}{ Grade11 \& higher } & $-0.227 * * *$ & $-0.186 * * *$ & $-0.117 * * *$ & $0.530 * * *$ \\
\hline & $(0.009)$ & $(0.011)$ & $(0.015)$ & $(0.026)$ \\
\hline $\mathrm{N}$ & 3210 & 3210 & 3210 & 3210 \\
\hline \multicolumn{5}{|c|}{ Daughters, 2005} \\
\hline \multirow[t]{2}{*}{ Grades1-6 } & $-0.205 * * *$ & $-0.046 * * *$ & 0.003 & $0.248 * * *$ \\
\hline & $(0.015)$ & $(0.005)$ & $(0.004)$ & $(0.021)$ \\
\hline \multirow[t]{2}{*}{ Grades 7-10 } & $-0.276 * * *$ & $-0.083 * * *$ & $-0.040 * * *$ & $0.398 * * *$ \\
\hline & $(0.017)$ & $(0.010)$ & $(0.013)$ & $(0.036)$ \\
\hline \multirow[t]{2}{*}{ Grade11 \& higher } & $-0.299 * * *$ & $-0.099 * * *$ & $-0.067 * * *$ & $0.465 * * *$ \\
\hline & $(0.014)$ & $(0.010)$ & $(0.014)$ & $(0.032)$ \\
\hline $\mathrm{N}$ & 2283 & 2283 & 2283 & 2283 \\
\hline \multicolumn{5}{|c|}{ Sons \& Daughters, 2013} \\
\hline \multirow[t]{2}{*}{ Grades $1-6$} & $-0.112 * * *$ & $-0.054 * * *$ & $-0.005 * *$ & $0.171 * * *$ \\
\hline & $(0.006)$ & $(0.004)$ & $(0.002)$ & $(0.010)$ \\
\hline \multirow[t]{2}{*}{ Grades 7-10 } & $-0.133 * * *$ & $-0.071 * * *$ & $-0.019 * * *$ & $0.223 * * *$ \\
\hline & $(0.008)$ & $(0.005)$ & $(0.005)$ & $(0.016)$ \\
\hline \multirow[t]{2}{*}{ Grade11 \& higher } & $-0.189 * * *$ & $-0.131 * * *$ & $-0.121 * * *$ & $0.441 * * *$ \\
\hline & $(0.006)$ & $(0.005)$ & $(0.009)$ & $(0.016)$ \\
\hline $\mathrm{N}$ & 7759 & 7759 & 7759 & 7759 \\
\hline \multicolumn{5}{|c|}{ Sons, 2013} \\
\hline \multirow[t]{2}{*}{ Grades1-6 } & $-0.102 * * *$ & $-0.081 * * *$ & $-0.016 * * *$ & $0.199 * * *$ \\
\hline & $(0.007)$ & $(0.006)$ & $(0.004)$ & $(0.014)$ \\
\hline \multirow[t]{2}{*}{ Grades 7-10 } & $-0.117 * * *$ & $-0.100 * * *$ & $-0.035 * * *$ & $0.253 * * *$ \\
\hline & $(0.008)$ & $(0.008)$ & $(0.008)$ & $(0.021)$ \\
\hline \multirow[t]{2}{*}{ Grade11 \& higher } & $-0.154 * * *$ & $-0.168 * * *$ & $-0.165 * * *$ & $0.487 * * *$ \\
\hline & $(0.007)$ & $(0.008)$ & $(0.014)$ & $(0.021)$ \\
\hline $\mathrm{N}$ & 4483 & 4483 & 4483 & 4483 \\
\hline \multicolumn{5}{|c|}{ Daughters, 2013} \\
\hline Grades 1-6 & $-0.119 * * *$ & $-0.032 * * *$ & 0.004 & $0.146 * * *$ \\
\hline
\end{tabular}




\begin{tabular}{cllll}
\hline & $(0.012)$ & $(0.004)$ & $(0.003)$ & $(0.016)$ \\
Grades 7-10 & $-0.153^{* * *}$ & $-0.046^{* * *}$ & -0.007 & $0.205^{* * *}$ \\
& $(0.014)$ & $(0.006)$ & $(0.005)$ & $(0.023)$ \\
Grade11 \& higher & $-0.227^{* * *}$ & $-0.091^{* * *}$ & $-0.078^{* * * *}$ & $0.396^{* * *}$ \\
& $(0.011)$ & $(0.007)$ & $(0.011)$ & $(0.023)$ \\
$\mathrm{N}$ & 3276 & 3276 & 3276 & 3276 \\
\hline
\end{tabular}

Robust standard errors in parentheses, with household clusters

$* * * \mathrm{p}<0.01, * * \mathrm{p}<0.05, * \mathrm{p}<0.1$

\subsubsection{Occupational status}

Table 5 reports unconditional probabilities from a transition matrix of the occupational status of children and their parents. The combined 2005 and 2013 sample reveals that occupationally children are spread more or less equally among the three possible states of children having had better, same or worse occupational status as their father. The Table also reports a statistically significant gender gap in occupational mobility. Accordingly, compared with daughters, sons are 4 percentage point more likely to occupy higher occupational status than their father and 4 percentage point less likely to occupy lower occupational status than their father, which are both found to be statistically significant. Splitting the sample by survey year reveals that the proportions of children with the same or better occupational status than their father has increased between 2005 and 2013, while that of children with a lower occupational status has declined in 2013. This appears to suggest an improvement in occupational mobility in 2013. No statistically significant occupational gender gap was found in 2005. On the other hand, statistically significant gender gap has been found in 2013 where, compared with daughters, sons are found to be 6 percentage points more likely to occupy higher occupational status than their father and 6 percentage points less likely to occupy lower occupational status. This suggests the improvement in occupational mobility highlighted earlier is weighted more by improvements in the occupational fortunes of sons.

Table 5: Child-father Occupational Status (\%)

\begin{tabular}{cllll}
\hline & $\begin{array}{l}\text { Sons \& daughters } \\
(1)\end{array}$ & $\begin{array}{l}\text { Sons } \\
(2)\end{array}$ & $\begin{array}{l}\text { Daughters } \\
(3)\end{array}$ & $\begin{array}{l}\text { Diff. } \\
(2-3)\end{array}$ \\
\hline $\begin{array}{c}\text { Combined 2005 \& 2013 sample }(N=13252) \\
\text { \% in a lower occupational group than father }\end{array}$ & 32.4 & 30.8 & 34.7 & $-4.0 * * *$ \\
\% in the same occupational group as father & 32.9 & 32.8 & 33.1 & -0.22 \\
$\%$ in higher occupational group than father & 34.6 & 36.4 & 32.2 & $4.2 * * *$ \\
Total & 100 & 100 & 100 & \\
\hline
\end{tabular}




\begin{tabular}{|c|c|c|c|c|}
\hline \multicolumn{5}{|l|}{2005 sample $(N=5493)$} \\
\hline$\%$ in a lower Occupational group than father & 35.9 & 35.4 & 36.6 & -1.2 \\
\hline$\%$ in the same Occupational group as father & 32.0 & 31.7 & 32.5 & -0.8 \\
\hline$\%$ in higher Occupational group than father & 32.1 & 33.0 & 30.9 & $2.1 *$ \\
\hline Total & 100 & 100 & 100 & \\
\hline \multicolumn{5}{|l|}{2013 sample $(N=7759)$} \\
\hline$\%$ in a lower Occupational group than father & 30.0 & 27.5 & 33.4 & $-6.0 * * *$ \\
\hline$\%$ in the same Occupational group as father & 33.6 & 33.7 & 33.5 & -0.3 \\
\hline$\%$ in higher Occupational group than father & 36.4 & 38.8 & 33.1 & $5.7 * * *$ \\
\hline Total & 100 & 100 & 100 & \\
\hline
\end{tabular}

$* * * \mathrm{p}<0.01, * * \mathrm{p}<0.05, * \mathrm{p}<0.1$

Authors own computation based on Ethiopian LFS 2005 and 2013.

Conditional marginal effects from the ordered probit models estimating intergenerational mobility in occupational status are reported in Table 6. The results reveal that compared with fathers without any occupation; children with fathers who have higher levels of occupational status are generally more likely to be in better occupational status. For example, compared with fathers with no occupation, children with parents in 'managerial and professional' occupations are 5 percentage points more likely to have a 'managerial and professional' occupation; and 12 percentage points less likely to have no or elementary occupations; or, 5 percentage points less likely to have a lower occupational status generally than their father in 2005. A similar picture emerges in 2013, but with marginal effects that are relatively higher in magnitude than those for 2005. For example, compared with fathers with no occupation, children with fathers that have a 'managerial and professional' occupation were only 5 percentage points less likely to have a lower occupational status in 2005, a lower figure than the 13 percentage points obtained for 2013. The marginal effects also reveal some gender differential in occupational mobility in that the estimated marginal effects are higher in magnitude for sons, thus suggesting a higher mobility for sons than daughters. For example, focusing on the highest occupational category, sons with fathers who have a 'managerial and professional' occupation are 16 percentage points more likely to occupy the same occupational status in 2013, while the corresponding figure for daughters is only 10 percentage points. Generally, controlling for father's occupation, sons are more (less) likely to have higher (lower) occupational statuses than daughters; and this is more apparent in 2013.

Table 6: Intergenerational Mobility in Occupational Status of Sons \& Daughters, Marginal Effects from Ordered Probit

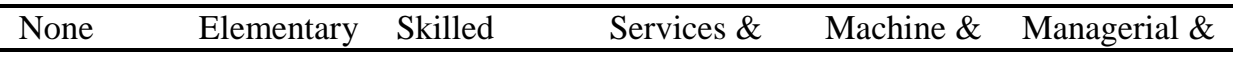




\begin{tabular}{|c|c|c|c|c|c|c|}
\hline & & & Agricultural & Sales & crafts & Professional \\
\hline \multicolumn{7}{|l|}{$\begin{array}{c}\text { Sons \& daughters, } \\
2005\end{array}$} \\
\hline \multirow[t]{2}{*}{ Elementary } & 0.036 & $0.001 * *$ & -0.002 & -0.009 & -0.016 & $-0.011^{*}$ \\
\hline & $(0.023)$ & $(0.001)$ & $(0.001)$ & $(0.006)$ & $(0.010)$ & $(0.006)$ \\
\hline \multirow[t]{2}{*}{ Skilled Agricultural } & $0.036 * *$ & $0.001 * *$ & $-0.002 * * *$ & $-0.009 * *$ & $-0.016^{* *}$ & $-0.011 * *$ \\
\hline & $(0.014)$ & $(0.001)$ & $(0.001)$ & $(0.004)$ & $(0.006)$ & $(0.004)$ \\
\hline \multirow[t]{2}{*}{ Services \& Sales } & -0.023 & -0.002 & 0.001 & 0.005 & 0.010 & 0.008 \\
\hline & $(0.018)$ & $(0.002)$ & $(0.001)$ & (0.004) & $(0.008)$ & $(0.006)$ \\
\hline \multirow[t]{2}{*}{ Machine operator } & $-0.057 * * *$ & $-0.006^{* * *}$ & $0.002 * * *$ & $0.013 * * *$ & $0.027 * * *$ & $0.021 * * *$ \\
\hline & (0.018) & $(0.002)$ & $(0.001)$ & $(0.004)$ & $(0.009)$ & $(0.007)$ \\
\hline \multirow{2}{*}{ Managerial \& Prof. } & $-0.108 * * *$ & $-0.016^{* *}$ & $0.002 *$ & $0.022 * * *$ & $0.053 * * *$ & $0.048 * * *$ \\
\hline & $(0.028)$ & $(0.006)$ & $(0.001)$ & $(0.005)$ & $(0.015)$ & $(0.016)$ \\
\hline $\mathrm{N}$ & 5493 & 5493 & 5493 & 5493 & 5493 & 5493 \\
\hline \multicolumn{7}{|l|}{ Sons, 2005} \\
\hline \multirow{2}{*}{ Elementary } & 0.043 & $0.004 *$ & -0.003 & -0.008 & -0.021 & -0.015 \\
\hline & $(0.028)$ & $(0.002)$ & $(0.002)$ & $(0.005)$ & (0.014) & (0.009) \\
\hline \multirow[t]{2}{*}{ Skilled Agricultural } & $0.034 *$ & $0.003 *$ & $-0.003 * *$ & $-0.006^{*}$ & $-0.017^{*}$ & $-0.012 *$ \\
\hline & $(0.017)$ & $(0.002)$ & $(0.001)$ & $(0.003)$ & (0.009) & $(0.006)$ \\
\hline \multirow[t]{2}{*}{ Services \& Sales } & -0.036 & -0.006 & $0.002 *$ & 0.006 & 0.019 & 0.015 \\
\hline & $(0.022)$ & (0.004) & $(0.001)$ & (0.003) & (0.012) & (0.010) \\
\hline \multirow[t]{2}{*}{ Machine operator } & -0.027 & -0.004 & 0.001 & 0.004 & 0.014 & 0.011 \\
\hline & $(0.023)$ & (0.004) & $(0.001)$ & $(0.004)$ & $(0.012)$ & $(0.010)$ \\
\hline \multirow[t]{2}{*}{ Managerial \& Prof. } & $-0.114 * * *$ & $-0.027 * *$ & 0.001 & $0.015 * * *$ & $0.063 * * *$ & $0.062 * *$ \\
\hline & $(0.033)$ & $(0.011)$ & $(0.002)$ & $(0.003)$ & $(0.019)$ & $(0.024)$ \\
\hline $\mathrm{N}$ & 3210 & 3210 & 3210 & 3210 & 3210 & 3210 \\
\hline \multicolumn{7}{|l|}{ Daughters, 2005} \\
\hline \multirow[t]{2}{*}{ Elementary } & 0.018 & -0.000 & -0.000 & -0.007 & -0.006 & -0.004 \\
\hline & (0.038) & $(0.001)$ & $(0.001)$ & $(0.015)$ & $(0.013)$ & (0.009) \\
\hline \multirow{2}{*}{ Skilled Agricultural } & 0.029 & -0.000 & -0.001 & -0.011 & -0.010 & -0.007 \\
\hline & $(0.023)$ & $(0.000)$ & $(0.001)$ & (0.009) & $(0.008)$ & $(0.005)$ \\
\hline \multirow[t]{2}{*}{ Services \& Sales } & 0.004 & 0.000 & -0.000 & -0.001 & -0.001 & -0.001 \\
\hline & $(0.030)$ & $(0.000)$ & $(0.001)$ & $(0.012)$ & $(0.011)$ & $(0.008)$ \\
\hline \multirow[t]{2}{*}{ Machine operator } & $-0.097 * * *$ & $-0.006 * *$ & $0.001 * * *$ & $0.033 * * *$ & $0.038 * * *$ & $0.031 * * *$ \\
\hline & $(0.028)$ & $(0.003)$ & $(0.000)$ & $(0.009)$ & $(0.012)$ & $(0.010)$ \\
\hline \multirow[t]{2}{*}{ Managerial \& Prof. } & $-0.095 *$ & -0.006 & $0.001 * * *$ & $0.032 * *$ & $0.037 *$ & 0.030 \\
\hline & $(0.049)$ & $(0.006)$ & $(0.000)$ & $(0.015)$ & $(0.020)$ & $(0.019)$ \\
\hline $\mathrm{N}$ & 2283 & 2283 & 2283 & 2283 & 2283 & 2283 \\
\hline \multicolumn{7}{|l|}{$\begin{array}{c}\text { Sons \& Daughters, } \\
2013\end{array}$} \\
\hline \multirow[t]{2}{*}{ Elementary } & $0.090 * * *$ & $0.008 * * *$ & $-0.007 * * *$ & $-0.022 * * *$ & $-0.023 * * *$ & $-0.046 * * *$ \\
\hline & (0.016) & $(0.001)$ & $(0.002)$ & $(0.004)$ & $(0.004)$ & $(0.008)$ \\
\hline \multirow[t]{2}{*}{ Skilled Agricultural } & $0.047 * * *$ & $0.006 * * *$ & $-0.003 * * *$ & $-0.011 * * *$ & $-0.013 * * *$ & $-0.027 * * *$ \\
\hline & $(0.011)$ & (0.001) & (0.001) & $(0.003)$ & $(0.003)$ & $(0.006)$ \\
\hline Services \& Sales & -0.000 & -0.000 & 0.000 & 0.000 & 0.000 & 0.000 \\
\hline & $(0.014)$ & $(0.002)$ & $(0.000)$ & $(0.003)$ & $(0.004)$ & $(0.009)$ \\
\hline Machine operator & $-0.032 *$ & -0.006 & $0.001^{*}$ & $0.007 *$ & $0.009^{*}$ & $0.022 *$ \\
\hline & $(0.018)$ & $(0.004)$ & $(0.000)$ & (0.004) & $(0.005)$ & (0.013) \\
\hline Managerial \& Prof. & $-0.137 * * *$ & $-0.039 * * *$ & $-0.009 * * *$ & $0.019 * * *$ & $0.039 * * *$ & $0.127 * * *$ \\
\hline & $(0.015)$ & $(0.006)$ & $(0.003)$ & $(0.002)$ & $(0.004)$ & $(0.019)$ \\
\hline $\mathrm{N}$ & 7759 & 7759 & 7759 & 7759 & 7759 & 7759 \\
\hline
\end{tabular}




\begin{tabular}{|c|c|c|c|c|c|c|}
\hline \multirow[t]{2}{*}{ Elementary } & $0.082 * * *$ & $0.013 * * *$ & $-0.006 * * *$ & $-0.014 * * *$ & $-0.028 * * *$ & $-0.046 * * *$ \\
\hline & $(0.020)$ & $(0.003)$ & $(0.002)$ & $(0.004)$ & $(0.007)$ & $(0.010)$ \\
\hline \multirow[t]{2}{*}{ Skilled Agricultural } & $0.038 * * *$ & $0.007 * * *$ & $-0.002 * *$ & $-0.006^{* * *}$ & $-0.013 * * *$ & $-0.024 * * *$ \\
\hline & $(0.014)$ & $(0.003)$ & $(0.001)$ & $(0.002)$ & $(0.005)$ & $(0.009)$ \\
\hline \multirow[t]{2}{*}{ Services \& Sales } & -0.009 & -0.002 & 0.000 & 0.001 & 0.003 & 0.007 \\
\hline & $(0.017)$ & $(0.004)$ & $(0.000)$ & $(0.003)$ & $(0.006)$ & $(0.012)$ \\
\hline \multirow[t]{2}{*}{ Machine operator } & $-0.050 * *$ & $-0.013 * *$ & -0.002 & $0.007 * * *$ & $0.018 * *$ & $0.040 * *$ \\
\hline & $(0.021)$ & $(0.006)$ & $(0.002)$ & $(0.002)$ & $(0.008)$ & $(0.018)$ \\
\hline \multirow[t]{2}{*}{ Managerial \& Prof. } & $-0.140 * * *$ & $-0.052 * * *$ & $-0.022 * * *$ & $0.009 * * *$ & $0.049 * * *$ & $0.155^{* * *} *$ \\
\hline & $(0.018)$ & $(0.009)$ & $(0.006)$ & $(0.002)$ & $(0.006)$ & $(0.027)$ \\
\hline $\mathrm{N}$ & 4483 & 4483 & 4483 & 4483 & 4483 & 4483 \\
\hline \multicolumn{7}{|l|}{ Daughters, 2013} \\
\hline \multirow[t]{2}{*}{ Elementary } & $0.106 * * *$ & 0.002 & $-0.007 * * *$ & $-0.038 * * *$ & $-0.015 * * *$ & $-0.048 * * *$ \\
\hline & $(0.027)$ & $(0.002)$ & $(0.002)$ & $(0.010)$ & $(0.004)$ & $(0.011)$ \\
\hline \multirow[t]{2}{*}{ Skilled Agricultural } & $0.050 * * *$ & $0.002 * *$ & $-0.003 * * *$ & $-0.017 * * *$ & $-0.007 * * *$ & $-0.025 * * *$ \\
\hline & $(0.019)$ & $(0.001)$ & $(0.001)$ & $(0.007)$ & $(0.003)$ & $(0.010)$ \\
\hline \multirow[t]{2}{*}{ Services \& Sales } & 0.016 & 0.001 & -0.001 & -0.006 & -0.002 & -0.009 \\
\hline & $(0.024)$ & $(0.002)$ & $(0.001)$ & $(0.008)$ & $(0.003)$ & $(0.013)$ \\
\hline \multirow[t]{2}{*}{ Machine operator } & -0.000 & -0.000 & 0.000 & 0.000 & 0.000 & 0.000 \\
\hline & $(0.032)$ & $(0.003)$ & $(0.001)$ & $(0.011)$ & $(0.005)$ & $(0.018)$ \\
\hline \multirow[t]{2}{*}{ Managerial \& Prof. } & $-0.128 * * *$ & $-0.024 * * *$ & -0.000 & $0.035 * * *$ & $0.020 * * *$ & $0.097 * * *$ \\
\hline & $(0.027)$ & $(0.007)$ & $(0.002)$ & $(0.006)$ & $(0.005)$ & $(0.025)$ \\
\hline $\mathrm{N}$ & 3276 & 3276 & 3276 & 3276 & 3276 & 3276 \\
\hline
\end{tabular}

Robust standard errors in parentheses, with household clusters

$* * * \mathrm{p}<0.01, * * \mathrm{p}<0.05, * \mathrm{p}<0.1$

\section{Summary and conclusion}

The paper examined the extent of intergenerational mobility in monetary and nonmonetary economic status between young adult children and their parents in Ethiopia using data from two of the three most recent and comprehensive national labour force surveys conducted in 2005 and 2013.

The use of both monetary and non-monetary economic statuses measures in examining intergenerational mobility provides a more comprehensive account of mobility than is provided by focusing exclusively on income (monetary) based measure of mobility as much of the literature does. Such exclusive focus may, as discussed in the paper, understate the influence of family background on economic and social inequality. On the other hand, focusing entirely on non-monetary measures runs the risk of misclassification and hence of obtaining biased estimates of intergenerational mobility.

The results obtained suggest that there is generally moderate "stickiness" in income mobility across generations in Ethiopia. Sons are found to have higher intergenerational 
income mobility. The paper finds increased income mobility between 2005 and 2013; and this appears to be driven largely by the marked increase in mobility at the median and lower quantiles of the child income distribution. On the other hand, there has been a decline in mobility particularly at the top income quantile. Comparing sons and daughters, the latter appeared to have gained some ground in intergenerational income mobility between 2005 and 2013, albeit this being at the median and lower quantiles of the income distribution for the most part. Still, this seems to have contributed to a reduction of the gender gap in intergenerational income mobility in 2013.

Similar patterns emerge in the intergenerational mobility in educational and occupational statuses, both overall and in terms of the differential patterns between sons and daughters. Accordingly, compared with daughters, sons are found to be more (less) likely to attain higher (lower) levels of education than their parents generally. On the other hand, there seems to have been a general decline in educational mobility between 2005 and 2013; and the decline in educational mobility appears to have been weighted more by the decline in daughter's attainment.

Occupationally too, sons are generally more (less) likely to have a 'better' ('worse') occupational status than their parents vis-à-vis daughters. Splitting the sample by survey year revealed that the proportions of children with the same or better occupational status than their father has increased between 2005 and 2013, while that of children with a lower occupational status has declined in 2013.

There is virtually no evidence on intergenerational mobility in the context of low income countries in general and Sub-Saharan Africa in particular. The paper thus provides some valuable insights into intergenerational mobility in these contexts. The use of mixed approaches involving monetary and non-monetary frameworks is likely to offer a broader account of intergenerational mobility, which may be important given possible measurement error in income. 


\section{References}

Atkinson, A. (1981), On intergenerational income mobility in Britain, Journal of Post-Keynesian Economics, 3, pp 194-218.

Atkinson, A., Maynard, A. and Trinder, C. (1983) Parents and Children: Incomes in Two Generations. London: Heinemann.

Becker, G. (1991), A Treatise on the Family. Cambridge, Massachusetts: Harvard University Press.

Becker, G. and Tomes, N. (1986), Human capital and the rise and fall of families, Journal of Labor Economics, 4, pp S1-S39.

Behrman, J. and Taubman, P. (1985) Intergenerational earnings mobility in the United States: some estimates and a test of Becker's intergenerational endowments model, Review of Economics and Statistics, 67, pp 144-151.

Behrman, J. and Taubman, P. (1990), The intergenerational correlation between children's adult earnings and their parents' income: Results from the Michigan Panel Survey of Income Dynamics, Review of Income and Wealth, 36, pp 115-127.

Binder, M. and Woodruff, C. (2002), Inequality and intergenerational mobility in schooling: The case of Mexico, Economic Development and Cultural Change, 50, pp 249-268

Binder, M. and Woodruff, C. (2002), Inequality and Intergenerational Mobility in Schooling: The Case of Mexico, Economic Development and Cultural Change, 50 (2), 249-267.

Bjorklund, A. and Chadwick, L. (2003), Intergenerational Income Mobility in Permanent and Separated Families, Economic Letters, 80, pp 239 - 246.

Bjorklund, A. and Jantti, M. (1997), Intergenerational income mobility in Sweden compared to the United States, American Economic Review, 87, pp 1009-1018.

Black, S., Devereux, P., Lundborg, P. and Majlesi, K (2015), Poor Little Rich Kids? The Determinants of the Intergenerational Transmission of Wealth, NBER Working Paper Series, Working Paper 21409.

Black, S. and Deverux, P. (2011), Recent Developments in Intergenerational Mobility, in Card, D. and O. Ashenfelter (eds.), Handbook of Labor Economics, 4 (B), Chapter 16, $1487-1541$.

Blau, F. and Kahn, L. (2000), Gender Differences in Pay, Journal of Economic Perspectives, 14 (4), pp. 75-99.

Bowles, S. (1972), Schooling and Inequality from Generation to Generation, Journal of Political Economy, pp S219 - S251.

Bowles, S. and Gintis, H. (2002), The Inheritance of Inequality, The Journal of Economic Perspectives, 16, pp 3-30.

Buchinsky, M. (1998), Recent advances in quantile regression models: A practical guide for empirical research, Journal of Human Resources, 3, 88-126.

Carmichael, F. (2000), Intergenerational mobility and occupational status in Britain, Applied Economics Letters, 7, pp 391-396.

Chadwick, L. and Solon, G. (2002), Intergenerational income mobility among daughters, American Economic Review, 92, pp 335-344.

Corak, M. (2001), Are the kids all right? Intergenerational mobility and child well-being in Canada, mimeo, Statistics Canada.

Corak, M. and Heisz, A. (1999), The intergenerational earnings and income mobility of Canadian men, Journal of Human Resources, 34, pp 504-533.

Couch, K. and Dunn, T. (1997), Intergenerational correlation in labour market status: A comparison of the United States and Germany, Journal of Human Resources, 32, pp 210-232.

Dearden, L., Machin, S. and Reed, H. (1997), Intergenerational mobility in Britain, Economic Journal, 107, pp 47-66. 
Dunn, C. (2004), Intergenerational transmission of lifetime earnings: New evidence from Brazil, Department of Economics and Population Studies Centre, University of Michigan.

Eide, E. and Showalter, M. (1999), Factors affecting the transmission of earnings across generations: A quantile regression approach. Journal of Human Resources, 34, pp 253-267.

Erikson, R. and Goldthorpe, J. (2002), Intergenerational Inequality: A Sociological Perspective, The Journal of Economic Perspectives, 16, pp 31-44.

Ermisch, J. and Francesconi, M. (2002), Intergenerational mobility in Britain: New evidence from the BHPS, mimeo, ISER, University of Essex.

Ferreira, S. and Veloso, F. (2011), Intergenerational Mobility of Wages in Brazil, Brazilian Review of Econometrics, 26 (2), 181-211.

Gang, I. and Zimmermann, K. (2000), Is Child Like Parent? Educational Attainment and Ethnic Origin, The Journal of Human Resources, 35, 550 - 569.

Gaviria, A. (2002), Intergenerational Mobility, Sibling Inequality and Borrowing Constraints, Economics of Education Review, 21, 331 - 340.

Goldberger, A. (1989), Economic and mechanical models of intergenerational transmission, American Economic Review, 79, pp 504-513.

Green, W. (2002), Econometric Analysis. New York: Prentice-Hall International.

Hagy, A. and Staniec, F. (2002), Immigrant Status, Race, and Institutional Choice in Higher Education, Economics of Education Review, 21, pp 381 - 392.

Han, S. and Mulligan, C. (2001), Human capital, heterogeneity and estimated degrees of intergenerational mobility, Economic Journal, 111, pp 207-243.

Hanushek, E. (1992), The Trade-off between Child Quantity and Quality, Journal of Political Economy, 100, Number 1, pp $84-117$.

Hertz, T. (2002), Intergenerational Economic Mobility of Black and White Family in the United States, Paper presented at the Society of Labor Economist, Annual Meeting.

Hotchkiss, J. and Pitts, M. (2007), The Role of Labor Market Intermittency in Explaining Gender Wage Differentials, The American Economic Review, 97 (2), pp. 417-421.

Johnson, P. (2002), Intergenerational Dependence in Education and Income, Applied Economic Letters, 9, pp $159-162$.

Koenker, R. and G. Bassett (1978), Regression quantiles, Econometrica, 46, 33-50.

Kolev, A. and Robles, P. (2010), Addressing the Gender Pay Gap in Ethiopia: How Crucial is the Quest for Educational Parity, Journal of African Economies, 19 (5), 718 - 767.

Lauer, C. (2003), Family Background, Cohort and Education: A French - German Comparison based on a Multivariate Ordered Probit Model of Educational Attainment, Labour Economics, 10, pp $231-251$.

Levine, D. and Mazumder, B. (2002), Choosing the right parents: Changes in the intergenerational transmission of inequality - between 1980 and the early 1990s, WP 2002-08, Federal Reserve Bank of Chicago.

Lien, D. and N. Balakrishnan (2005), On Regression Analysis with Data Cleaning via Trimming, Winsorization, and Dichotomization, Communication in Statistics - Simulation and Computation, 34 (4), 839 - 849.

Lillard, D. (2001), Earnings and income mobility: Cross-national estimates of the intergenerational mobility in earnings, Viertejahrshefte Zur Wirtschaftsforschung, 20, pp 51-58.

Mazumder, B. (2001), Earnings mobility in the US: A new look at intergenerational inequality, mimeo, Federal Reserve Bank of Chicago.

Mulligan, C. (1997), Parental Priorities and Economic Inequality, Chicago: Univ. of Chicago Press

Mulligan, C. (1999), Galton versus the human capital approach to inheritance, Journal of Political Economy, 107, pp S184-S224. 
Naga, R. (2002), Estimating the intergenerational correlation of incomes: An errors-in-variables framework, Economica, 69, pp 69-91.

Nguyen, A., Haile, G. and Taylor, J (2005), Ethnic and Gender Differences in Intergenerational Mobility: a study of 26-year-olds in the USA, Scottish Journal of Political Economy, 52(4), pp. 544-564.

Nickell, S. (1982), The determinants of occupational success in Britain, Review of Economic Studies, 49, pp 43-53.

Osterbacka, E. (2001), Family background and economic status in Finland, Scandinavian Journal of Economics, 103, pp 467-484.

Osterberg, T. (2000), Intergenerational income mobility in Sweden: What do tax-data show? Review of Income and Wealth, 46, pp 421-436.

Painter, G. and Levine, D. (2000), Family Structure and Youths' Outcomes: Which Correlations are Causal? The Journal of Human Resources, 35, pp 524 - 549.

Peters, E. (1992), Patterns of intergenerational mobility in income and earnings, Review of Economics and Statistics, 73, pp 456-466.

Phipps, S., Burton, P. and Lethbridge, L. (2001), In and out of the Labour Market: Long-Term Income Consequences of Child-Related Interruptions to Women's Paid Work, The Canadian Journal of Economics, 34 (2), 411-429.

Piraino, P. (2014), Intergenerational Earnings Mobility and Equality of opportunities in South Africa, SALDRU Working Paper Series, No. 131, South Africa.

Solon, G. (1992), Intergenerational income mobility in the United States, American Economic Review, 82, pp 393-408.

Solon, G. (2002), Cross-Country Differences in Intergenerational Earnings Mobility, The Journal of Economic Perspectives, 16, pp 59-66.

Thomas, D. (1996), Education across generations in South Africa, American Economic Review, 86, pp 330-334.

UNDP (2013), Humanity Divided: Confronting Inequality in Developing Countries, United Nations Development Programme, Bureau for Development Policy, NY.

Valero-Gil, J. and Tijierina-Guajardo, J. (2002), Effects of education on the intergenerational transmission of labour income in Mexico, Eastern Economic Journal, 28, pp 381392.

Zimmerman, D. (1992), Regression toward mediocrity in economic stature, American Economic Review, 82, pp 409-429. 


\section{Appendix}

Table A1: Descriptive Statistics, LFS 2005 and 2013

\begin{tabular}{|c|c|c|c|c|c|c|c|c|}
\hline Variable & Mean & $\begin{array}{l}\text { Std. } \\
\text { Dev. }\end{array}$ & Min & Max & Mean & $\begin{array}{l}\text { Std. } \\
\text { Dev. }\end{array}$ & Min & $\operatorname{Max}$ \\
\hline & \multicolumn{4}{|c|}{2005} & \multicolumn{4}{|c|}{2013} \\
\hline \multicolumn{9}{|c|}{ Demographic and household characteristics } \\
\hline Age & 28.16 & 2.88 & 25 & 35 & 28.38 & 3.03 & 25 & 35 \\
\hline Female & 0.42 & 0.49 & 0 & 1 & 0.42 & 0.49 & 0 & 1 \\
\hline \multicolumn{9}{|l|}{ Child's highest grade: } \\
\hline don't read & 0.21 & 0.41 & 0 & 1 & 0.15 & 0.36 & 0 & 1 \\
\hline primary or less & 0.16 & 0.36 & 0 & 1 & 0.14 & 0.34 & 0 & 1 \\
\hline grade $7-10$ & 0.24 & 0.43 & 0 & 1 & 0.33 & 0.47 & 0 & 1 \\
\hline grade $11 \&$ above & 0.39 & 0.49 & 0 & 1 & 0.39 & 0.49 & 0 & 1 \\
\hline \multicolumn{9}{|l|}{ Parent's highest grade: } \\
\hline don't read & 0.60 & 0.49 & 0 & 1 & 0.48 & 0.50 & 0 & 1 \\
\hline primary or less & 0.24 & 0.43 & 0 & 1 & 0.27 & 0.44 & 0 & 1 \\
\hline grade $7-10$ & 0.07 & 0.26 & 0 & 1 & 0.11 & 0.31 & 0 & 1 \\
\hline grade $11 \&$ above & 0.09 & 0.29 & 0 & 1 & 0.14 & 0.35 & 0 & 1 \\
\hline \multicolumn{9}{|l|}{ Child's occupation: } \\
\hline none & 0.35 & 0.48 & 0 & 1 & 0.30 & 0.46 & 0 & 1 \\
\hline elementary & 0.19 & 0.39 & 0 & 1 & 0.18 & 0.38 & 0 & 1 \\
\hline skilled agriculture & 0.08 & 0.27 & 0 & 1 & 0.13 & 0.34 & 0 & 1 \\
\hline services & 0.16 & 0.37 & 0 & 1 & 0.15 & 0.36 & 0 & 1 \\
\hline craft \& machinery & 0.15 & 0.36 & 0 & 1 & 0.10 & 0.30 & 0 & 1 \\
\hline managerial \& professional & 0.06 & 0.25 & 0 & 1 & 0.14 & 0.34 & 0 & 1 \\
\hline \multicolumn{9}{|l|}{ Parent's occupation: } \\
\hline none & 0.40 & 0.49 & 0 & 1 & 0.39 & 0.49 & 0 & 1 \\
\hline elementary & 0.07 & 0.26 & 0 & 1 & 0.10 & 0.30 & 0 & 1 \\
\hline skilled agriculture & 0.23 & 0.42 & 0 & 1 & 0.23 & 0.42 & 0 & 1 \\
\hline services & 0.13 & 0.33 & 0 & 1 & 0.14 & 0.34 & 0 & 1 \\
\hline craft \& machinery & 0.13 & 0.34 & 0 & 1 & 0.07 & 0.25 & 0 & 1 \\
\hline managerial \& professional & 0.05 & 0.21 & 0 & 1 & 0.08 & 0.26 & 0 & 1 \\
\hline Two parent household & 0.45 & 0.50 & 0 & 1 & 0.45 & 0.50 & 0 & 1 \\
\hline No. of siblings & 3.64 & 2.05 & 1 & 22 & 3.38 & 1.88 & 1 & 10 \\
\hline \multicolumn{9}{|l|}{ Region: } \\
\hline Tigray & 0.06 & 0.23 & 0 & 1 & 0.06 & 0.24 & 0 & 1 \\
\hline Afar & 0.02 & 0.14 & 0 & 1 & 0.02 & 0.13 & 0 & 1 \\
\hline Amhara & 0.14 & 0.35 & 0 & 1 & 0.14 & 0.34 & 0 & 1 \\
\hline Oromia & 0.17 & 0.38 & 0 & 1 & 0.16 & 0.36 & 0 & 1 \\
\hline Somalie & 0.03 & 0.18 & 0 & 1 & 0.03 & 0.16 & 0 & 1 \\
\hline Benishangul-Gumuz & 0.01 & 0.12 & 0 & 1 & 0.02 & 0.13 & 0 & 1 \\
\hline SNNPR & 0.14 & 0.35 & 0 & 1 & 0.15 & 0.36 & 0 & 1 \\
\hline Gambela & 0.00 & 0.06 & 0 & 1 & 0.02 & 0.14 & 0 & 1 \\
\hline Harari & 0.03 & 0.16 & 0 & 1 & 0.03 & 0.16 & 0 & 1 \\
\hline Addis Ababa & 0.36 & 0.48 & 0 & 1 & 0.35 & 0.48 & 0 & 1 \\
\hline Dire Dawa & 0.03 & 0.16 & 0 & 1 & 0.03 & 0.18 & 0 & 1 \\
\hline No. of children & 5,493 & & & & 7,759 & & & \\
\hline \multicolumn{9}{|l|}{ Earnings characteristics } \\
\hline Log of child's income & 5.64 & 0.77 & 3.33 & 7.09 & 7.04 & 0.72 & 5.30 & 8.27 \\
\hline Log of father's income & 5.92 & 0.87 & 3.40 & 7.01 & 7.15 & 0.73 & 5.29 & 8.26 \\
\hline Log of father's 'permanent' income & 5.65 & 0.60 & 3.61 & 6.91 & 6.96 & 0.61 & 4.71 & 8.07 \\
\hline No. of children & 397 & & & & 789 & & & \\
\hline
\end{tabular}


Table A2: Income Equation Predicting Father's "Permanent" Income

\begin{tabular}{|c|c|}
\hline \multirow[t]{2}{*}{ Age (father's) } & $0.055 * * *$ \\
\hline & $(0.003)$ \\
\hline \multirow[t]{2}{*}{ Age squared } & $-0.001 * * *$ \\
\hline & $(0.000)$ \\
\hline \multirow[t]{2}{*}{ No. of siblings } & $-0.011 * * *$ \\
\hline & $(0.003)$ \\
\hline \multirow[t]{2}{*}{ Two parent household } & $0.031 * * *$ \\
\hline & $(0.010)$ \\
\hline \multirow[t]{2}{*}{ Grades 1-6 } & $0.211 * * *$ \\
\hline & $(0.019)$ \\
\hline \multirow[t]{2}{*}{ Grades 7-10 } & $0.454 * * *$ \\
\hline & $(0.019)$ \\
\hline \multirow[t]{2}{*}{ Grade 11 or higher } & $0.866 * * *$ \\
\hline & $(0.020)$ \\
\hline \multirow[t]{2}{*}{ Elementary occupation } & $-0.197 * * *$ \\
\hline & $(0.062)$ \\
\hline \multirow[t]{2}{*}{ Skilled Agricultural } & 0.004 \\
\hline & $(0.069)$ \\
\hline \multirow[t]{2}{*}{ Services \& Sales } & 0.094 \\
\hline & $(0.062)$ \\
\hline \multirow[t]{2}{*}{ Machine operator } & $0.282 * * *$ \\
\hline & $(0.062)$ \\
\hline \multirow[t]{2}{*}{ Managerial \& Professional } & $0.444 * * *$ \\
\hline & $(0.062)$ \\
\hline \multirow[t]{2}{*}{ Manufacturing } & $0.109 * * *$ \\
\hline & $(0.026)$ \\
\hline \multirow[t]{2}{*}{ Wholesale \& retail trade } & $0.083 * * *$ \\
\hline & $(0.030)$ \\
\hline \multirow[t]{2}{*}{ Other industries } & $0.218 * * *$ \\
\hline & $(0.023)$ \\
\hline \multirow[t]{2}{*}{ Tigray } & 0.013 \\
\hline & $(0.020)$ \\
\hline \multirow[t]{2}{*}{ Afar } & $0.208 * * *$ \\
\hline & $(0.020)$ \\
\hline \multirow[t]{2}{*}{ Amhara } & $-0.023 *$ \\
\hline & $(0.014)$ \\
\hline \multirow[t]{2}{*}{ Somalie } & $0.288 * * *$ \\
\hline & $(0.025)$ \\
\hline \multirow[t]{2}{*}{ Benishangul-Gumuz } & $0.069 * * *$ \\
\hline & $(0.020)$ \\
\hline SNNPR & $-0.091 * * *$ \\
\hline & $(0.014)$ \\
\hline Gambela & $0.195 * * *$ \\
\hline & $(0.021)$ \\
\hline Harari & $0.051 * *$ \\
\hline & $(0.024)$ \\
\hline Addis Ababa & $0.129 * * *$ \\
\hline & $(0.012)$ \\
\hline Dire Dawa & $0.090 * * *$ \\
\hline & $(0.026)$ \\
\hline 2013 & $1.178 * * *$ \\
\hline & $(0.008)$ \\
\hline Constant & $3.826 * * *$ \\
\hline & $(0.082)$ \\
\hline R-squared & 0.676 \\
\hline $\mathrm{N}$ & 21248 \\
\hline
\end{tabular}


Table A3: Intergenerational Mobility in Educational Attainment, Marginal Effects from Ordered Probit, Sons and Daughters (2005)

\begin{tabular}{|c|c|c|c|c|}
\hline & No education & Grades1-6 & Grades 7-10 & Grade11 \& higher \\
\hline \multirow[t]{2}{*}{ Grades1-6 } & $-0.178 * * *$ & $-0.068 * * *$ & -0.000 & $0.246 * * *$ \\
\hline & $(0.008)$ & $(0.005)$ & $(0.003)$ & $(0.013)$ \\
\hline \multirow{2}{*}{ Grades 7-10 } & $-0.233 * * *$ & $-0.114 * * *$ & $-0.044 * * *$ & $0.391 * * *$ \\
\hline & $(0.009)$ & $(0.008)$ & $(0.008)$ & $(0.022)$ \\
\hline \multirow[t]{2}{*}{ Grade11 \& higher } & $-0.260 * * *$ & $-0.146 * * *$ & $-0.093 * * *$ & $0.499 * * *$ \\
\hline & $(0.008)$ & $(0.008)$ & $(0.010)$ & $(0.021)$ \\
\hline \multirow[t]{2}{*}{ Age } & $-0.052 * *$ & $-0.014 * *$ & $0.002^{*}$ & $0.064 * *$ \\
\hline & $(0.026)$ & $(0.007)$ & $(0.001)$ & $(0.032)$ \\
\hline \multirow[t]{2}{*}{ Age squared } & $0.001 * *$ & $0.000 * *$ & $-0.000 *$ & $-0.001 * *$ \\
\hline & $(0.000)$ & $(0.000)$ & $(0.000)$ & $(0.001)$ \\
\hline \multirow[t]{2}{*}{ Female } & $0.038 * * *$ & $0.010 * * *$ & $-0.001 * * *$ & $-0.047 * * *$ \\
\hline & $(0.008)$ & $(0.002)$ & $(0.001)$ & $(0.010)$ \\
\hline \multirow[t]{2}{*}{ Two parent $\mathrm{HH}$} & $0.062 * * *$ & $0.017 * * *$ & $-0.002 * * *$ & $-0.076 * * *$ \\
\hline & $(0.008)$ & $(0.002)$ & $(0.001)$ & $(0.010)$ \\
\hline \multirow[t]{2}{*}{ No. of siblings } & -0.001 & -0.000 & 0.000 & 0.002 \\
\hline & $(0.002)$ & $(0.001)$ & $(0.000)$ & $(0.002)$ \\
\hline \multirow[t]{2}{*}{ Tigray } & 0.004 & 0.001 & -0.001 & -0.004 \\
\hline & $(0.020)$ & $(0.005)$ & $(0.003)$ & $(0.022)$ \\
\hline \multirow[t]{2}{*}{ Afar } & $0.275^{* * *}$ & 0.008 & $-0.084 * * *$ & $-0.199 * * *$ \\
\hline & $(0.045)$ & $(0.007)$ & $(0.017)$ & $(0.023)$ \\
\hline \multirow[t]{2}{*}{ Amhara } & $0.041 * *$ & $0.009 * *$ & $-0.008 * *$ & $-0.042 * *$ \\
\hline & $(0.016)$ & $(0.003)$ & $(0.003)$ & $(0.017)$ \\
\hline \multirow[t]{2}{*}{ Somalie } & $0.225 * * *$ & $0.014 * * *$ & $-0.065 * * *$ & $-0.174 * * *$ \\
\hline & $(0.035)$ & $(0.004)$ & $(0.013)$ & $(0.021)$ \\
\hline \multirow[t]{2}{*}{ Benishangul-Gumuz } & $0.154 * * *$ & $0.018^{* * *}$ & $-0.040 * * *$ & $-0.131 * * *$ \\
\hline & $(0.043)$ & $(0.003)$ & $(0.014)$ & $(0.030)$ \\
\hline \multirow[t]{2}{*}{ SNNPR } & 0.023 & 0.005 & -0.004 & -0.024 \\
\hline & $(0.015)$ & $(0.004)$ & $(0.003)$ & $(0.016)$ \\
\hline \multirow[t]{2}{*}{ Gambela } & -0.024 & -0.007 & 0.003 & 0.028 \\
\hline & $(0.053)$ & $(0.016)$ & $(0.005)$ & $(0.064)$ \\
\hline \multirow[t]{2}{*}{ Harari } & $-0.065 * * *$ & $-0.022 * *$ & $0.004 * *$ & $0.083 * *$ \\
\hline & $(0.023)$ & $(0.009)$ & $(0.002)$ & $(0.033)$ \\
\hline \multirow[t]{2}{*}{ Addis Ababa } & $-0.149 * * *$ & $-0.072 * * *$ & $-0.020 * * *$ & $0.241 * * *$ \\
\hline & $(0.011)$ & $(0.005)$ & $(0.003)$ & $(0.015)$ \\
\hline \multirow[t]{2}{*}{ Dire Dawa } & 0.017 & 0.004 & -0.003 & -0.018 \\
\hline & $(0.029)$ & $(0.007)$ & $(0.005)$ & $(0.031)$ \\
\hline $\mathrm{N}$ & 5493 & 5493 & 5493 & 5493 \\
\hline
\end{tabular}

Robust standard errors in parentheses, with household clusters

$* * * \mathrm{p}<0.01, * * \mathrm{p}<0.05, * \mathrm{p}<0.1$ 
Table A4: Intergenerational Mobility in Educational Attainment, Marginal Effects from Ordered Probit, Sons (2005)

\begin{tabular}{|c|c|c|c|c|}
\hline & No education & Grades1-6 & Grades 7-10 & Grade11 \& higher \\
\hline \multirow[t]{2}{*}{ Grades1-6 } & $-0.158 * * *$ & $-0.087 * * *$ & -0.004 & $0.249 * * *$ \\
\hline & $(0.010)$ & $(0.007)$ & $(0.004)$ & $(0.017)$ \\
\hline \multirow[t]{2}{*}{ Grades 7-10 } & $-0.202 * * *$ & $-0.140 * * *$ & $-0.049 * * *$ & $0.391 * * *$ \\
\hline & $(0.010)$ & $(0.011)$ & $(0.011)$ & $(0.028)$ \\
\hline \multirow[t]{2}{*}{ Grade11 \& higher } & $-0.227 * * *$ & $-0.186 * * *$ & $-0.117 * * *$ & $0.530 * * *$ \\
\hline & $(0.009)$ & $(0.011)$ & $(0.015)$ & $(0.026)$ \\
\hline \multirow[t]{2}{*}{ Age } & 0.004 & 0.002 & -0.000 & -0.006 \\
\hline & $(0.031)$ & $(0.012)$ & $(0.001)$ & $(0.043)$ \\
\hline \multirow[t]{2}{*}{ Age squared } & -0.000 & -0.000 & 0.000 & 0.000 \\
\hline & $(0.001)$ & $(0.000)$ & $(0.000)$ & $(0.001)$ \\
\hline \multirow[t]{2}{*}{ Two parent $\mathrm{HH}$} & $0.077 * * *$ & $0.031 * * *$ & -0.002 & $-0.106 * * *$ \\
\hline & $(0.009)$ & $(0.004)$ & $(0.001)$ & $(0.013)$ \\
\hline \multirow[t]{2}{*}{ No. of siblings } & $-0.005 * *$ & $-0.002 * *$ & 0.000 & $0.007 * *$ \\
\hline & $(0.002)$ & $(0.001)$ & $(0.000)$ & $(0.003)$ \\
\hline \multirow[t]{2}{*}{ Tigray } & -0.017 & -0.007 & 0.003 & 0.022 \\
\hline & $(0.021)$ & $(0.009)$ & $(0.003)$ & $(0.027)$ \\
\hline \multirow[t]{2}{*}{ Afar } & $0.245 * * *$ & $0.024 * * *$ & $-0.081 * * *$ & $-0.188 * * *$ \\
\hline & $(0.060)$ & $(0.008)$ & $(0.024)$ & $(0.032)$ \\
\hline \multirow[t]{2}{*}{ Amhara } & 0.031 & 0.010 & -0.006 & -0.035 \\
\hline & $(0.020)$ & $(0.007)$ & $(0.004)$ & $(0.022)$ \\
\hline \multirow[t]{2}{*}{ Somalie } & $0.219 * * *$ & $0.026^{* * *}$ & $-0.070 * * *$ & $-0.175 * * *$ \\
\hline & $(0.044)$ & $(0.006)$ & $(0.017)$ & $(0.027)$ \\
\hline \multirow[t]{2}{*}{ Benishangul-Gumuz } & $0.089 * *$ & $0.023 * * *$ & -0.023 & $-0.089 * *$ \\
\hline & $(0.045)$ & $(0.008)$ & $(0.014)$ & $(0.039)$ \\
\hline \multirow[t]{2}{*}{ SNNPR } & 0.018 & 0.006 & -0.003 & -0.021 \\
\hline & $(0.017)$ & $(0.006)$ & $(0.003)$ & $(0.020)$ \\
\hline \multirow[t]{2}{*}{ Gambela } & $-0.104 * * *$ & $-0.063^{*}$ & -0.006 & $0.173 * *$ \\
\hline & $(0.039)$ & $(0.034)$ & $(0.016)$ & $(0.088)$ \\
\hline \multirow[t]{2}{*}{ Harari } & $-0.073 * * *$ & $-0.038 * *$ & 0.003 & $0.108 * * *$ \\
\hline & $(0.023)$ & $(0.015)$ & $(0.004)$ & $(0.040)$ \\
\hline \multirow[t]{2}{*}{ Addis Ababa } & $-0.129 * * *$ & $-0.089 * * *$ & $-0.021 * * *$ & $0.240 * * *$ \\
\hline & $(0.013)$ & $(0.008)$ & $(0.004)$ & $(0.019)$ \\
\hline \multirow[t]{2}{*}{ Dire Dawa } & 0.046 & 0.014 & -0.010 & -0.050 \\
\hline & $(0.037)$ & $(0.010)$ & $(0.009)$ & $(0.037)$ \\
\hline $\mathrm{N}$ & 3210 & 3210 & 3210 & 3210 \\
\hline
\end{tabular}

Robust standard errors in parentheses, with household clusters $* * * \mathrm{p}<0.01, * * \mathrm{p}<0.05, * \mathrm{p}<0.1$ 
Table A5: Intergenerational Mobility in Educational Attainment, Marginal Effects from Ordered Probit, Daughters (2005)

\begin{tabular}{|c|c|c|c|c|}
\hline & No education & Grades1-6 & Grades 7-10 & Grade11 \& higher \\
\hline \multirow[t]{2}{*}{ Grades 1-6 } & $-0.205^{* * *}$ & $-0.046 * * *$ & 0.003 & $0.248 * * *$ \\
\hline & $(0.015)$ & $(0.005)$ & $(0.004)$ & $(0.021)$ \\
\hline \multirow[t]{2}{*}{ Grades 7-10 } & $-0.276 * * *$ & $-0.083 * * *$ & $-0.040 * * *$ & $0.398 * * *$ \\
\hline & $(0.017)$ & $(0.010)$ & $(0.013)$ & $(0.036)$ \\
\hline \multirow[t]{2}{*}{ Grade11 \& higher } & $-0.299 * * *$ & $-0.099 * * *$ & $-0.067 * * *$ & $0.465 * * *$ \\
\hline & $(0.014)$ & $(0.010)$ & $(0.014)$ & $(0.032)$ \\
\hline \multirow[t]{2}{*}{ Age } & $-0.121 * * *$ & $-0.019 * * *$ & $0.005 * *$ & $0.135 * * *$ \\
\hline & $(0.043)$ & $(0.007)$ & $(0.003)$ & $(0.047)$ \\
\hline \multirow[t]{2}{*}{ Age squared } & $0.002 * * *$ & $0.000 * * *$ & $-0.000 * *$ & $-0.002 * * *$ \\
\hline & $(0.001)$ & $(0.000)$ & $(0.000)$ & $(0.001)$ \\
\hline \multirow[t]{2}{*}{ Two parent $\mathrm{HH}$} & $0.036 * *$ & $0.006^{* *}$ & $-0.002 *$ & $-0.040 * *$ \\
\hline & $(0.015)$ & $(0.002)$ & $(0.001)$ & $(0.016)$ \\
\hline \multirow[t]{2}{*}{ No. of siblings } & 0.004 & 0.001 & -0.000 & -0.005 \\
\hline & $(0.003)$ & $(0.001)$ & $(0.000)$ & $(0.004)$ \\
\hline \multirow[t]{2}{*}{ Tigray } & 0.042 & 0.005 & -0.007 & -0.041 \\
\hline & $(0.041)$ & $(0.004)$ & $(0.007)$ & $(0.038)$ \\
\hline \multirow[t]{2}{*}{ Afar } & $0.313 * * *$ & -0.007 & $-0.089 * * *$ & $-0.217 * * *$ \\
\hline & $(0.067)$ & $(0.011)$ & $(0.025)$ & $(0.034)$ \\
\hline \multirow[t]{2}{*}{ Amhara } & $0.054 * *$ & $0.006 * *$ & $-0.009 * *$ & $-0.051 * *$ \\
\hline & $(0.026)$ & $(0.003)$ & $(0.005)$ & $(0.025)$ \\
\hline \multirow[t]{2}{*}{ Somalie } & $0.211 * * *$ & 0.005 & $-0.053 * * *$ & $-0.164 * * *$ \\
\hline & $(0.057)$ & $(0.005)$ & $(0.019)$ & $(0.036)$ \\
\hline \multirow[t]{2}{*}{ Benishangul-Gumuz } & $0.299 * * *$ & -0.005 & $-0.084 * * *$ & $-0.210 * * *$ \\
\hline & $(0.084)$ & $(0.013)$ & $(0.031)$ & $(0.042)$ \\
\hline \multirow[t]{2}{*}{ SNNPR } & 0.034 & 0.004 & -0.005 & -0.033 \\
\hline & $(0.027)$ & $(0.003)$ & $(0.004)$ & $(0.027)$ \\
\hline \multirow[t]{2}{*}{ Gambela } & 0.099 & $0.008 * *$ & -0.019 & -0.089 \\
\hline & $(0.097)$ & $(0.004)$ & $(0.024)$ & $(0.076)$ \\
\hline \multirow[t]{2}{*}{ Harari } & -0.034 & -0.006 & 0.003 & 0.037 \\
\hline & $(0.049)$ & $(0.009)$ & $(0.003)$ & $(0.055)$ \\
\hline \multirow[t]{2}{*}{ Addis Ababa } & $-0.169 * * *$ & $-0.050 * * *$ & $-0.018 * * *$ & $0.237 * * *$ \\
\hline & $(0.019)$ & $(0.005)$ & $(0.005)$ & $(0.023)$ \\
\hline \multirow[t]{2}{*}{ Dire Dawa } & -0.019 & -0.003 & 0.002 & 0.020 \\
\hline & $(0.046)$ & $(0.008)$ & $(0.004)$ & $(0.049)$ \\
\hline $\mathrm{N}$ & 2283 & 2283 & 2283 & 2283 \\
\hline
\end{tabular}

Robust standard errors in parentheses, with household clusters $* * * \mathrm{p}<0.01, * * \mathrm{p}<0.05, * \mathrm{p}<0.1$ 
Table A6: Intergenerational Mobility in Educational Attainment, Marginal Effects from Ordered Probit, Sons and Daughters (2013)

\begin{tabular}{|c|c|c|c|c|}
\hline & No education & Grades1-6 & Grades 7-10 & Grade11 \& higher \\
\hline \multirow[t]{2}{*}{ Grades1-6 } & $-0.112 * * *$ & $-0.054 * * *$ & $-0.005^{* *}$ & $0.171 * * *$ \\
\hline & $(0.006)$ & $(0.004)$ & $(0.002)$ & $(0.010)$ \\
\hline \multirow{2}{*}{ Grades 7-10 } & $-0.133 * * *$ & $-0.071 * * *$ & $-0.019 * * *$ & $0.223 * * *$ \\
\hline & $(0.008)$ & $(0.005)$ & $(0.005)$ & $(0.016)$ \\
\hline \multirow[t]{2}{*}{ Grade11 \& higher } & $-0.189 * * *$ & $-0.131 * * *$ & $-0.121 * * *$ & $0.441 * * *$ \\
\hline & $(0.006)$ & $(0.005)$ & $(0.009)$ & $(0.016)$ \\
\hline \multirow[t]{2}{*}{ Age } & $-0.045 * * *$ & $-0.020 * * *$ & $-0.005 * *$ & $0.070 * * *$ \\
\hline & $(0.017)$ & $(0.008)$ & $(0.002)$ & $(0.026)$ \\
\hline \multirow[t]{2}{*}{ Age squared } & $0.001 * * *$ & $0.000 * * *$ & $0.000 * *$ & $-0.001 * * *$ \\
\hline & $(0.000)$ & $(0.000)$ & $(0.000)$ & $(0.000)$ \\
\hline \multirow[t]{2}{*}{ Female } & $0.044 * * *$ & $0.020 * * *$ & $0.005 * * *$ & $-0.069 * * *$ \\
\hline & $(0.005)$ & $(0.002)$ & $(0.001)$ & $(0.008)$ \\
\hline \multirow[t]{2}{*}{ Two parent $\mathrm{HH}$} & $0.019 * * *$ & $0.009 * * *$ & $0.002 * * *$ & $-0.030 * * *$ \\
\hline & $(0.006)$ & $(0.002)$ & $(0.001)$ & $(0.009)$ \\
\hline \multirow[t]{2}{*}{ No. of siblings } & $0.005 * * *$ & $0.002 * * *$ & $0.001 * * *$ & $-0.008 * * *$ \\
\hline & $(0.001)$ & $(0.001)$ & $(0.000)$ & $(0.002)$ \\
\hline \multirow[t]{2}{*}{ Tigray } & -0.020 & -0.008 & 0.003 & 0.026 \\
\hline & $(0.014)$ & $(0.006)$ & $(0.002)$ & $(0.018)$ \\
\hline \multirow[t]{2}{*}{ Afar } & $0.191 * * *$ & $0.033 * * *$ & $-0.071 * * *$ & $-0.153 * * *$ \\
\hline & $(0.035)$ & $(0.003)$ & $(0.017)$ & $(0.021)$ \\
\hline \multirow[t]{2}{*}{ Amhara } & 0.003 & 0.001 & -0.000 & -0.003 \\
\hline & $(0.012)$ & $(0.004)$ & $(0.002)$ & $(0.014)$ \\
\hline \multirow[t]{2}{*}{ Somalie } & $0.142 * * *$ & $0.031 * * *$ & $-0.048 * * *$ & $-0.125 * * *$ \\
\hline & $(0.028)$ & $(0.004)$ & $(0.012)$ & $(0.020)$ \\
\hline \multirow[t]{2}{*}{ Benishangul-Gumuz } & 0.041 & $0.013^{*}$ & -0.009 & -0.044 \\
\hline & $(0.028)$ & $(0.008)$ & $(0.008)$ & $(0.028)$ \\
\hline \multirow[t]{2}{*}{ SNNPR } & $-0.031 * * *$ & $-0.013 * * *$ & $0.003 * *$ & $0.041 * * *$ \\
\hline & $(0.011)$ & $(0.004)$ & $(0.001)$ & $(0.014)$ \\
\hline \multirow[t]{2}{*}{ Gambela } & 0.016 & 0.006 & -0.003 & -0.018 \\
\hline & $(0.025)$ & $(0.008)$ & $(0.005)$ & $(0.028)$ \\
\hline \multirow[t]{2}{*}{ Harari } & $-0.091 * * *$ & $-0.047 * * *$ & -0.008 & $0.146^{* * *}$ \\
\hline & $(0.016)$ & $(0.010)$ & $(0.007)$ & $(0.031)$ \\
\hline \multirow[t]{2}{*}{ Addis Ababa } & $-0.137 * * *$ & $-0.087 * * *$ & $-0.051 * * *$ & $0.275^{* * *}$ \\
\hline & $(0.008)$ & $(0.005)$ & $(0.004)$ & $(0.013)$ \\
\hline \multirow[t]{2}{*}{ Dire Dawa } & -0.030 & -0.012 & $0.003 * *$ & 0.039 \\
\hline & $(0.019)$ & $(0.008)$ & $(0.001)$ & $(0.026)$ \\
\hline $\mathrm{N}$ & 7759 & 7759 & 7759 & 7759 \\
\hline
\end{tabular}

Robust standard errors in parentheses, with household clusters

$* * * \mathrm{p}<0.01, * * \mathrm{p}<0.05, * \mathrm{p}<0.1$ 
Table A7: Intergenerational Mobility in Educational Attainment, Marginal Effects from Ordered Probit, Sons (2013)

\begin{tabular}{|c|c|c|c|c|}
\hline & No education & Grades1-6 & Grades 7-10 & Grade11 \& higher \\
\hline \multirow[t]{2}{*}{ Grades1-6 } & $-0.102 * * *$ & $-0.081 * * *$ & $-0.016 * * *$ & $0.199 * * *$ \\
\hline & $(0.007)$ & $(0.006)$ & $(0.004)$ & $(0.014)$ \\
\hline \multirow[t]{2}{*}{ Grades 7-10 } & $-0.117 * * *$ & $-0.100 * * *$ & $-0.035^{* * *}$ & $0.253 * * *$ \\
\hline & $(0.008)$ & $(0.008)$ & $(0.008)$ & $(0.021)$ \\
\hline \multirow[t]{2}{*}{ Grade11 \& higher } & $-0.154 * * *$ & $-0.168 * * *$ & $-0.165 * * *$ & $0.487 * * *$ \\
\hline & $(0.007)$ & $(0.008)$ & $(0.014)$ & $(0.021)$ \\
\hline \multirow[t]{2}{*}{ Age } & $-0.054 * * *$ & $-0.038 * * *$ & $-0.011 * * *$ & $0.103 * * *$ \\
\hline & $(0.019)$ & $(0.013)$ & $(0.004)$ & $(0.036)$ \\
\hline \multirow[t]{2}{*}{ Age squared } & $0.001 * * *$ & $0.001 * * *$ & $0.000 * *$ & $-0.002 * * *$ \\
\hline & $(0.000)$ & $(0.000)$ & $(0.000)$ & $(0.001)$ \\
\hline \multirow[t]{2}{*}{ Two parent $\mathrm{HH}$} & $0.037 * * *$ & $0.026 * * *$ & $0.008 * * *$ & $-0.071 * * *$ \\
\hline & $(0.006)$ & $(0.004)$ & $(0.002)$ & $(0.011)$ \\
\hline \multirow[t]{2}{*}{ No. of siblings } & 0.002 & 0.001 & 0.000 & -0.004 \\
\hline & $(0.002)$ & $(0.001)$ & $(0.000)$ & $(0.003)$ \\
\hline \multirow[t]{2}{*}{ Tigray } & -0.005 & -0.003 & 0.000 & 0.008 \\
\hline & $(0.014)$ & $(0.009)$ & $(0.001)$ & $(0.023)$ \\
\hline \multirow[t]{2}{*}{ Afar } & $0.175 * * *$ & $0.058 * * *$ & $-0.066 * * *$ & $-0.167 * * *$ \\
\hline & $(0.043)$ & $(0.007)$ & $(0.022)$ & $(0.028)$ \\
\hline \multirow[t]{2}{*}{ Amhara } & 0.018 & 0.011 & -0.002 & -0.027 \\
\hline & $(0.013)$ & $(0.008)$ & $(0.002)$ & $(0.018)$ \\
\hline \multirow[t]{2}{*}{ Somalie } & $0.088 * * *$ & $0.041 * * *$ & $-0.025 * *$ & $-0.104 * * *$ \\
\hline & $(0.031)$ & $(0.011)$ & $(0.013)$ & $(0.029)$ \\
\hline \multirow[t]{2}{*}{ Benishangul-Gumuz } & 0.022 & 0.013 & -0.003 & -0.032 \\
\hline & $(0.028)$ & $(0.015)$ & $(0.006)$ & $(0.037)$ \\
\hline \multirow[t]{2}{*}{ SNNPR } & -0.018 & -0.012 & 0.000 & 0.030 \\
\hline & $(0.011)$ & $(0.007)$ & $(0.001)$ & $(0.018)$ \\
\hline \multirow[t]{2}{*}{ Gambela } & $-0.037^{*}$ & -0.028 & -0.003 & 0.068 \\
\hline & $(0.020)$ & $(0.017)$ & $(0.005)$ & $(0.042)$ \\
\hline \multirow[t]{2}{*}{ Harari } & $-0.056 * * *$ & $-0.046 * * *$ & -0.011 & $0.114 * * *$ \\
\hline & $(0.017)$ & $(0.017)$ & $(0.009)$ & $(0.042)$ \\
\hline \multirow[t]{2}{*}{ Addis Ababa } & $-0.092 * * *$ & $-0.090 * * *$ & $-0.052 * * *$ & $0.234 * * *$ \\
\hline & $(0.008)$ & $(0.007)$ & $(0.005)$ & $(0.017)$ \\
\hline \multirow[t]{2}{*}{ Dire Dawa } & $-0.053 * * *$ & $-0.042 * * *$ & -0.009 & $0.104 * * *$ \\
\hline & $(0.016)$ & $(0.015)$ & $(0.008)$ & $(0.038)$ \\
\hline $\mathrm{N}$ & 4483 & 4483 & 4483 & 4483 \\
\hline
\end{tabular}

Robust standard errors in parentheses, with household clusters $* * * \mathrm{p}<0.01, * * \mathrm{p}<0.05, * \mathrm{p}<0.1$ 
Table A8: Intergenerational Mobility in Educational Attainment, Marginal Effects from Ordered Probit, Daughters (2013)

\begin{tabular}{|c|c|c|c|c|}
\hline & No education & Grades1-6 & Grades 7-10 & Grade11 \& higher \\
\hline \multirow[t]{2}{*}{ Grades1-6 } & $-0.119 * * *$ & $-0.032 * * *$ & 0.004 & $0.146^{* * *}$ \\
\hline & $(0.012)$ & $(0.004)$ & $(0.003)$ & $(0.016)$ \\
\hline \multirow{2}{*}{ Grades 7-10 } & $-0.153 * * *$ & $-0.046 * * *$ & -0.007 & $0.205^{* * * *}$ \\
\hline & $(0.014)$ & $(0.006)$ & $(0.005)$ & $(0.023)$ \\
\hline \multirow[t]{2}{*}{ Grade11 \& higher } & $-0.227 * * *$ & $-0.091 * * *$ & $-0.078 * * *$ & $0.396 * * *$ \\
\hline & $(0.011)$ & $(0.007)$ & $(0.011)$ & $(0.023)$ \\
\hline \multirow[t]{2}{*}{ Age } & -0.022 & -0.006 & -0.001 & 0.029 \\
\hline & $(0.030)$ & $(0.008)$ & $(0.001)$ & $(0.039)$ \\
\hline \multirow[t]{2}{*}{ Age squared } & 0.000 & 0.000 & 0.000 & -0.001 \\
\hline & $(0.001)$ & $(0.000)$ & $(0.000)$ & $(0.001)$ \\
\hline \multirow[t]{2}{*}{ Two parent $\mathrm{HH}$} & -0.010 & -0.003 & -0.000 & 0.013 \\
\hline & $(0.010)$ & $(0.003)$ & $(0.000)$ & $(0.013)$ \\
\hline \multirow[t]{2}{*}{ No. of siblings } & $0.009 * * *$ & $0.002 * * *$ & $0.000^{*}$ & $-0.011 * * *$ \\
\hline & $(0.003)$ & $(0.001)$ & $(0.000)$ & $(0.003)$ \\
\hline \multirow[t]{2}{*}{ Tigray } & $-0.048^{*}$ & -0.010 & $0.008^{*}$ & 0.050 \\
\hline & $(0.028)$ & $(0.007)$ & $(0.004)$ & $(0.031)$ \\
\hline \multirow[t]{2}{*}{ Afar } & $0.200 * * *$ & $0.010 * *$ & $-0.073 * * *$ & $-0.137 * * *$ \\
\hline & $(0.057)$ & $(0.004)$ & $(0.026)$ & $(0.031)$ \\
\hline \multirow[t]{2}{*}{ Amhara } & -0.027 & -0.005 & 0.005 & 0.027 \\
\hline & $(0.023)$ & $(0.005)$ & $(0.004)$ & $(0.023)$ \\
\hline \multirow[t]{2}{*}{ Somalie } & $0.215 * * *$ & $0.009 * *$ & $-0.080 * * *$ & $-0.144 * * *$ \\
\hline & $(0.050)$ & $(0.004)$ & $(0.022)$ & $(0.027)$ \\
\hline \multirow[t]{2}{*}{ Benishangul-Gumuz } & 0.071 & $0.009^{*}$ & -0.021 & -0.059 \\
\hline & $(0.057)$ & $(0.005)$ & $(0.019)$ & $(0.043)$ \\
\hline \multirow[t]{2}{*}{ SNNPR } & $-0.054 * * *$ & $-0.012 * *$ & $0.009 * *$ & $0.057 * * *$ \\
\hline & $(0.021)$ & $(0.005)$ & $(0.004)$ & $(0.022)$ \\
\hline \multirow[t]{2}{*}{ Gambela } & 0.077 & $0.009 * *$ & -0.023 & $-0.063^{*}$ \\
\hline & $(0.047)$ & $(0.004)$ & $(0.016)$ & $(0.035)$ \\
\hline \multirow[t]{2}{*}{ Harari } & $-0.137 * * *$ & $-0.041 * * *$ & 0.001 & $0.178 * * *$ \\
\hline & $(0.030)$ & $(0.012)$ & $(0.009)$ & $(0.047)$ \\
\hline \multirow[t]{2}{*}{ Addis Ababa } & $-0.199 * * *$ & $-0.076 * * *$ & $-0.041 * * *$ & $0.316^{* * *}$ \\
\hline & $(0.017)$ & $(0.006)$ & $(0.006)$ & $(0.020)$ \\
\hline \multirow[t]{2}{*}{ Dire Dawa } & 0.040 & 0.006 & -0.011 & -0.035 \\
\hline & $(0.041)$ & $(0.005)$ & $(0.012)$ & $(0.034)$ \\
\hline $\mathrm{N}$ & 3276 & 3276 & 3276 & 3276 \\
\hline
\end{tabular}

Robust standard errors in parentheses, with household clusters

$* * * \mathrm{p}<0.01, * * \mathrm{p}<0.05, * \mathrm{p}<0.1$ 
Table A9: Intergenerational Mobility in Occupational Status, Marginal Effects from Ordered Probit, Sons and Daughters (2005)

\begin{tabular}{|c|c|c|c|c|c|c|}
\hline & None & Elementary & $\begin{array}{l}\text { Skilled } \\
\text { Agricultural }\end{array}$ & $\begin{array}{l}\text { Services \& } \\
\text { Sales }\end{array}$ & $\begin{array}{l}\text { Machine } \\
\text { operator \& } \\
\text { crafts }\end{array}$ & $\begin{array}{l}\text { Managerial } \\
\& \\
\text { Professional }\end{array}$ \\
\hline \multirow[t]{2}{*}{ Elementary } & 0.036 & $0.001 * *$ & -0.002 & -0.009 & -0.016 & $-0.011 *$ \\
\hline & $(0.023)$ & $(0.001)$ & $(0.001)$ & $(0.006)$ & $(0.010)$ & $(0.006)$ \\
\hline \multirow[t]{2}{*}{ Skilled Agricultural } & $0.036 * *$ & $0.001 * *$ & $-0.002 * * *$ & $-0.009 * *$ & $-0.016 * *$ & $-0.011 * *$ \\
\hline & $(0.014)$ & $(0.001)$ & $(0.001)$ & $(0.004)$ & $(0.006)$ & $(0.004)$ \\
\hline \multirow[t]{2}{*}{ Services \& Sales } & -0.023 & -0.002 & 0.001 & 0.005 & 0.010 & 0.008 \\
\hline & $(0.018)$ & $(0.002)$ & $(0.001)$ & $(0.004)$ & $(0.008)$ & $(0.006)$ \\
\hline \multirow[t]{2}{*}{ Machine operator } & $-0.057 * * *$ & $-0.006^{* * *}$ & $0.002 * * *$ & $0.013 * * *$ & $0.027 * * *$ & $0.021 * * *$ \\
\hline & $(0.018)$ & $(0.002)$ & $(0.001)$ & $(0.004)$ & $(0.009)$ & $(0.007)$ \\
\hline \multirow[t]{2}{*}{ Managerial \& Prof. } & $-0.108 * * *$ & $-0.016 * *$ & $0.002 *$ & $0.022 * * *$ & $0.053 * * *$ & $0.048 * * *$ \\
\hline & $(0.028)$ & $(0.006)$ & $(0.001)$ & $(0.005)$ & $(0.015)$ & $(0.016)$ \\
\hline \multirow[t]{2}{*}{ Age } & $-0.068 *$ & $-0.005^{*}$ & $0.003^{*}$ & $0.016^{*}$ & $0.031 *$ & $0.023^{*}$ \\
\hline & $(0.036)$ & $(0.003)$ & $(0.002)$ & $(0.009)$ & $(0.016)$ & $(0.012)$ \\
\hline \multirow[t]{2}{*}{ Age squared } & $0.001 *$ & 0.000 & $-0.000^{*}$ & $-0.000^{*}$ & $-0.000^{*}$ & $-0.000^{*}$ \\
\hline & $(0.001)$ & $(0.000)$ & $(0.000)$ & $(0.000)$ & $(0.000)$ & $(0.000)$ \\
\hline \multirow[t]{2}{*}{ Female } & $0.069 * * *$ & $0.005 * * *$ & $-0.003 * * *$ & $-0.017 * * *$ & $-0.031 * * *$ & $-0.023 * * *$ \\
\hline & $(0.011)$ & $(0.001)$ & $(0.001)$ & $(0.003)$ & $(0.005)$ & $(0.004)$ \\
\hline \multirow[t]{2}{*}{ Two parent $\mathrm{HH}$} & -0.005 & -0.000 & 0.000 & 0.001 & 0.002 & 0.002 \\
\hline & $(0.012)$ & $(0.001)$ & $(0.001)$ & $(0.003)$ & $(0.005)$ & $(0.004)$ \\
\hline \multirow[t]{2}{*}{ No. of siblings } & 0.001 & 0.000 & -0.000 & -0.000 & -0.001 & -0.000 \\
\hline & $(0.003)$ & $(0.000)$ & $(0.000)$ & $(0.001)$ & $(0.001)$ & $(0.001)$ \\
\hline \multirow[t]{2}{*}{ Tigrary } & 0.017 & 0.002 & -0.001 & -0.004 & -0.008 & -0.006 \\
\hline & $(0.024)$ & $(0.002)$ & $(0.001)$ & $(0.006)$ & $(0.011)$ & $(0.008)$ \\
\hline \multirow[t]{2}{*}{ Afar } & $0.080 * *$ & $0.004 * * *$ & -0.004 & $-0.020^{*}$ & $-0.035 * *$ & $-0.025 * *$ \\
\hline & $(0.041)$ & $(0.001)$ & $(0.003)$ & $(0.011)$ & $(0.017)$ & $(0.011)$ \\
\hline \multirow[t]{2}{*}{ Amhara } & $0.033 *$ & $0.003^{*}$ & $-0.001 *$ & $-0.008 *$ & $-0.015^{*}$ & $-0.011 *$ \\
\hline & $(0.017)$ & $(0.001)$ & $(0.001)$ & $(0.004)$ & $(0.008)$ & $(0.006)$ \\
\hline \multirow[t]{2}{*}{ Somalie } & $0.138 * * *$ & 0.001 & $-0.009 * * *$ & $-0.036 * * *$ & $-0.057 * * *$ & $-0.037 * * *$ \\
\hline & $(0.034)$ & $(0.003)$ & $(0.003)$ & $(0.009)$ & $(0.013)$ & $(0.007)$ \\
\hline \multirow[t]{2}{*}{ Benishangul-Gumuz } & -0.048 & -0.007 & $0.001 * *$ & 0.010 & 0.024 & 0.021 \\
\hline & $(0.034)$ & $(0.006)$ & $(0.000)$ & $(0.006)$ & $(0.017)$ & $(0.016)$ \\
\hline \multirow[t]{2}{*}{ SNNPR } & 0.007 & 0.001 & -0.000 & -0.002 & -0.003 & -0.003 \\
\hline & $(0.017)$ & $(0.002)$ & $(0.001)$ & $(0.004)$ & $(0.008)$ & $(0.006)$ \\
\hline \multirow[t]{2}{*}{ Gambela } & $0.422 * * *$ & -0.062 & $-0.044 * * *$ & $-0.118 * * *$ & $-0.133 * * *$ & $-0.066 * * *$ \\
\hline & $(0.114)$ & $(0.041)$ & $(0.017)$ & $(0.031)$ & $(0.022)$ & $(0.007)$ \\
\hline \multirow[t]{2}{*}{ Harari } & 0.011 & 0.001 & -0.000 & -0.003 & -0.005 & -0.004 \\
\hline & $(0.037)$ & $(0.003)$ & $(0.001)$ & $(0.009)$ & $(0.017)$ & $(0.013)$ \\
\hline \multirow[t]{2}{*}{ Addis Ababa } & 0.017 & 0.002 & -0.001 & -0.004 & -0.008 & -0.006 \\
\hline & $(0.016)$ & $(0.002)$ & $(0.001)$ & $(0.004)$ & $(0.008)$ & $(0.006)$ \\
\hline \multirow[t]{2}{*}{ Dire Dawa } & $0.072 *$ & $0.004 * * *$ & -0.004 & $-0.018 *$ & $-0.032 * *$ & $-0.022 * *$ \\
\hline & $(0.037)$ & $(0.001)$ & $(0.002)$ & $(0.010)$ & $(0.015)$ & $(0.010)$ \\
\hline $\mathrm{N}$ & 5493 & 5493 & 5493 & 5493 & 5493 & 5493 \\
\hline
\end{tabular}

Robust standard errors in parentheses, with household clusters $* * * \mathrm{p}<0.01, * * \mathrm{p}<0.05, * \mathrm{p}<0.1$ 
Table A10: Intergenerational Mobility in Occupational Status, Marginal Effects from Ordered Probit, Sons (2005)

\begin{tabular}{|c|c|c|c|c|c|c|}
\hline & None & Elementary & $\begin{array}{l}\text { Skilled } \\
\text { Agricultural }\end{array}$ & $\begin{array}{l}\text { Services \& } \\
\text { Sales }\end{array}$ & $\begin{array}{l}\text { Machine } \\
\text { operator \& } \\
\text { crafts }\end{array}$ & $\begin{array}{l}\text { Managerial } \\
\& \\
\text { Professional }\end{array}$ \\
\hline \multirow[t]{2}{*}{ Elementary } & 0.043 & $0.004 *$ & -0.003 & -0.008 & -0.021 & -0.015 \\
\hline & $(0.028)$ & $(0.002)$ & $(0.002)$ & $(0.005)$ & $(0.014)$ & $(0.009)$ \\
\hline \multirow[t]{2}{*}{ Skilled Agricultural } & $0.034 *$ & $0.003 *$ & $-0.003 * *$ & $-0.006^{*}$ & $-0.017 *$ & $-0.012 *$ \\
\hline & $(0.017)$ & $(0.002)$ & $(0.001)$ & $(0.003)$ & $(0.009)$ & $(0.006)$ \\
\hline \multirow[t]{2}{*}{ Services \& Sales } & -0.036 & -0.006 & $0.002 *$ & 0.006 & 0.019 & 0.015 \\
\hline & $(0.022)$ & $(0.004)$ & $(0.001)$ & $(0.003)$ & $(0.012)$ & $(0.010)$ \\
\hline \multirow[t]{2}{*}{ Machine operator } & -0.027 & -0.004 & 0.001 & 0.004 & 0.014 & 0.011 \\
\hline & $(0.023)$ & $(0.004)$ & $(0.001)$ & $(0.004)$ & $(0.012)$ & $(0.010)$ \\
\hline \multirow[t]{2}{*}{ Managerial \& Prof. } & $-0.114 * * *$ & $-0.027 * *$ & 0.001 & $0.015 * * *$ & $0.063 * * *$ & $0.062 * *$ \\
\hline & $(0.033)$ & $(0.011)$ & $(0.002)$ & $(0.003)$ & $(0.019)$ & $(0.024)$ \\
\hline \multirow[t]{2}{*}{ Age } & -0.066 & -0.008 & 0.004 & 0.011 & 0.034 & 0.026 \\
\hline & $(0.047)$ & $(0.006)$ & $(0.003)$ & $(0.008)$ & $(0.024)$ & $(0.018)$ \\
\hline \multirow[t]{2}{*}{ Age squared } & 0.001 & 0.000 & -0.000 & -0.000 & -0.000 & -0.000 \\
\hline & $(0.001)$ & $(0.000)$ & $(0.000)$ & $(0.000)$ & $(0.000)$ & $(0.000)$ \\
\hline \multirow[t]{2}{*}{ Two parent $\mathrm{HH}$} & -0.003 & -0.000 & 0.000 & 0.000 & 0.001 & 0.001 \\
\hline & $(0.014)$ & $(0.002)$ & $(0.001)$ & $(0.002)$ & $(0.007)$ & $(0.006)$ \\
\hline \multirow[t]{2}{*}{ No. of siblings } & 0.003 & 0.000 & -0.000 & -0.001 & -0.002 & -0.001 \\
\hline & $(0.003)$ & $(0.000)$ & $(0.000)$ & $(0.001)$ & $(0.002)$ & $(0.001)$ \\
\hline \multirow[t]{2}{*}{ Tigray } & -0.008 & -0.001 & 0.000 & 0.001 & 0.004 & 0.003 \\
\hline & $(0.031)$ & $(0.004)$ & $(0.002)$ & $(0.005)$ & $(0.016)$ & $(0.012)$ \\
\hline \multirow[t]{2}{*}{ Afar } & 0.037 & 0.003 & -0.003 & -0.006 & -0.018 & -0.013 \\
\hline & $(0.049)$ & $(0.004)$ & $(0.004)$ & $(0.009)$ & $(0.024)$ & $(0.016)$ \\
\hline \multirow[t]{2}{*}{ Amhara } & 0.023 & 0.002 & -0.002 & -0.004 & -0.012 & -0.008 \\
\hline & $(0.023)$ & $(0.002)$ & $(0.002)$ & $(0.004)$ & $(0.012)$ & $(0.008)$ \\
\hline \multirow[t]{2}{*}{ Somalie } & $0.107 * * *$ & $0.004 *$ & $-0.010 * *$ & $-0.020 * *$ & $-0.050 * * *$ & $-0.031 * * *$ \\
\hline & $(0.041)$ & $(0.002)$ & $(0.005)$ & $(0.008)$ & $(0.018)$ & $(0.010)$ \\
\hline \multirow[t]{2}{*}{ Benishangul-Gumuz } & -0.050 & -0.008 & $0.002 *$ & 0.008 & 0.026 & 0.022 \\
\hline & $(0.037)$ & $(0.008)$ & $(0.001)$ & $(0.005)$ & $(0.020)$ & $(0.018)$ \\
\hline \multirow[t]{2}{*}{ SNNPR } & -0.003 & -0.000 & 0.000 & 0.000 & 0.001 & 0.001 \\
\hline & $(0.021)$ & $(0.003)$ & $(0.001)$ & $(0.003)$ & $(0.011)$ & $(0.008)$ \\
\hline \multirow[t]{2}{*}{ Gambela } & $0.507 * * *$ & -0.100 & $-0.082 * *$ & $-0.095^{* * *}$ & $-0.161 * * *$ & $-0.069 * * *$ \\
\hline & $(0.180)$ & $(0.084)$ & $(0.036)$ & $(0.029)$ & $(0.029)$ & (0.008) \\
\hline \multirow[t]{2}{*}{ Harari } & 0.033 & 0.003 & -0.002 & -0.006 & -0.016 & -0.012 \\
\hline & $(0.048)$ & $(0.004)$ & $(0.004)$ & $(0.008)$ & $(0.023)$ & $(0.016)$ \\
\hline \multirow[t]{2}{*}{ Addis Ababa } & -0.029 & -0.004 & 0.001 & 0.005 & 0.015 & 0.012 \\
\hline & $(0.021)$ & $(0.003)$ & $(0.001)$ & $(0.003)$ & $(0.011)$ & $(0.008)$ \\
\hline \multirow[t]{2}{*}{ Dire Dawa } & 0.033 & 0.003 & -0.002 & -0.006 & -0.016 & -0.011 \\
\hline & $(0.047)$ & $(0.004)$ & $(0.004)$ & $(0.008)$ & $(0.023)$ & $(0.015)$ \\
\hline $\mathrm{N}$ & 3210 & 3210 & 3210 & 3210 & 3210 & 3210 \\
\hline
\end{tabular}

Robust standard errors in parentheses, with household clusters

$* * * \mathrm{p}<0.01, * * \mathrm{p}<0.05, * \mathrm{p}<0.1$ 
Table A11: Intergenerational Mobility in Occupational Status, Marginal Effects from Ordered Probit, Daughters (2005)

\begin{tabular}{|c|c|c|c|c|c|c|}
\hline & None & Elementary & $\begin{array}{l}\text { Skilled } \\
\text { Agricultural }\end{array}$ & $\begin{array}{l}\text { Services \& } \\
\text { Sales }\end{array}$ & $\begin{array}{l}\text { Machine } \\
\text { operator \& } \\
\text { crafts }\end{array}$ & $\begin{array}{l}\text { Managerial } \\
\& \\
\text { Professional }\end{array}$ \\
\hline \multirow[t]{2}{*}{ Elementary } & 0.018 & -0.000 & -0.000 & -0.007 & -0.006 & -0.004 \\
\hline & $(0.038)$ & $(0.001)$ & $(0.001)$ & $(0.015)$ & $(0.013)$ & $(0.009)$ \\
\hline \multirow[t]{2}{*}{ Skilled Agricultural } & 0.029 & -0.000 & -0.001 & -0.011 & -0.010 & -0.007 \\
\hline & $(0.023)$ & $(0.000)$ & $(0.001)$ & $(0.009)$ & $(0.008)$ & $(0.005)$ \\
\hline \multirow[t]{2}{*}{ Services \& Sales } & 0.004 & 0.000 & -0.000 & -0.001 & -0.001 & -0.001 \\
\hline & $(0.030)$ & $(0.000)$ & $(0.001)$ & $(0.012)$ & $(0.011)$ & $(0.008)$ \\
\hline \multirow[t]{2}{*}{ Machine operator } & $-0.097 * * *$ & $-0.006^{* *}$ & $0.001 * * *$ & $0.033 * * *$ & $0.038 * * *$ & $0.031 * * *$ \\
\hline & $(0.028)$ & $(0.003)$ & $(0.000)$ & $(0.009)$ & $(0.012)$ & $(0.010)$ \\
\hline \multirow[t]{2}{*}{ Managerial \& Prof. } & $-0.095^{*}$ & -0.006 & $0.001 * * *$ & $0.032 * *$ & $0.037 *$ & 0.030 \\
\hline & $(0.049)$ & $(0.006)$ & $(0.000)$ & $(0.015)$ & $(0.020)$ & $(0.019)$ \\
\hline \multirow[t]{2}{*}{ Age } & -0.055 & -0.001 & 0.001 & 0.020 & 0.020 & 0.015 \\
\hline & $(0.057)$ & $(0.001)$ & $(0.001)$ & $(0.021)$ & $(0.021)$ & $(0.015)$ \\
\hline \multirow[t]{2}{*}{ Age squared } & 0.001 & 0.000 & -0.000 & -0.000 & -0.000 & -0.000 \\
\hline & $(0.001)$ & $(0.000)$ & $(0.000)$ & $(0.000)$ & $(0.000)$ & $(0.000)$ \\
\hline \multirow[t]{2}{*}{ Two parent $\mathrm{HH}$} & -0.012 & -0.000 & 0.000 & 0.004 & 0.004 & 0.003 \\
\hline & $(0.020)$ & $(0.000)$ & $(0.000)$ & $(0.007)$ & $(0.007)$ & $(0.005)$ \\
\hline \multirow[t]{2}{*}{ No. of siblings } & -0.001 & -0.000 & 0.000 & 0.000 & 0.000 & 0.000 \\
\hline & $(0.005)$ & $(0.000)$ & $(0.000)$ & $(0.002)$ & $(0.002)$ & $(0.001)$ \\
\hline \multirow[t]{2}{*}{ Tigray } & 0.056 & 0.003 & -0.001 & -0.020 & -0.022 & -0.017 \\
\hline & $(0.038)$ & $(0.002)$ & $(0.001)$ & $(0.014)$ & $(0.014)$ & $(0.011)$ \\
\hline \multirow[t]{2}{*}{ Afar } & $0.150 * *$ & -0.000 & -0.003 & $-0.057^{*}$ & $-0.052 * *$ & $-0.037 * * *$ \\
\hline & $(0.072)$ & $(0.006)$ & $(0.003)$ & $(0.030)$ & $(0.022)$ & $(0.013)$ \\
\hline \multirow[t]{2}{*}{ Amhara } & $0.050 *$ & 0.003 & $-0.001 *$ & $-0.017 *$ & $-0.019 *$ & $-0.015^{*}$ \\
\hline & $(0.026)$ & $(0.002)$ & $(0.000)$ & $(0.009)$ & $(0.010)$ & $(0.008)$ \\
\hline \multirow[t]{2}{*}{ Somalie } & $0.173 * * *$ & -0.003 & $-0.004 *$ & $-0.067 * * *$ & $-0.059 * * *$ & $-0.041 * * *$ \\
\hline & $(0.060)$ & $(0.006)$ & $(0.002)$ & $(0.025)$ & $(0.018)$ & $(0.011)$ \\
\hline \multirow[t]{2}{*}{ Benishangul-Gumuz } & -0.070 & -0.009 & -0.000 & 0.020 & 0.030 & 0.030 \\
\hline & $(0.065)$ & $(0.012)$ & $(0.001)$ & $(0.015)$ & $(0.029)$ & $(0.032)$ \\
\hline \multirow[t]{2}{*}{ SNNPR } & 0.018 & 0.001 & -0.000 & -0.006 & -0.007 & -0.006 \\
\hline & $(0.029)$ & $(0.002)$ & $(0.000)$ & $(0.010)$ & $(0.012)$ & $(0.010)$ \\
\hline \multirow[t]{2}{*}{ Gambela } & $0.363 * * *$ & -0.039 & $-0.014^{*}$ & $-0.149 * * *$ & $-0.102 * * *$ & $-0.059 * * *$ \\
\hline & $(0.133)$ & $(0.037)$ & $(0.008)$ & $(0.057)$ & $(0.025)$ & $(0.011)$ \\
\hline \multirow[t]{2}{*}{ Harari } & -0.019 & -0.002 & 0.000 & 0.006 & 0.008 & 0.007 \\
\hline & $(0.059)$ & $(0.006)$ & $(0.000)$ & $(0.018)$ & $(0.024)$ & $(0.022)$ \\
\hline \multirow[t]{2}{*}{ Addis Ababa } & $0.093 * * *$ & 0.003 & $-0.002 * * *$ & $-0.034 * * *$ & $-0.034 * * *$ & $-0.026 * * *$ \\
\hline & $(0.026)$ & $(0.002)$ & $(0.001)$ & $(0.010)$ & $(0.010)$ & $(0.008)$ \\
\hline \multirow[t]{2}{*}{ Dire Dawa } & $0.127 * *$ & 0.001 & -0.003 & $-0.047 * *$ & $-0.045 * *$ & $-0.033 * * *$ \\
\hline & $(0.059)$ & $(0.004)$ & $(0.002)$ & $(0.024)$ & $(0.019)$ & $(0.012)$ \\
\hline $\mathrm{N}$ & 2283 & 2283 & 2283 & 2283 & 2283 & 2283 \\
\hline
\end{tabular}

Robust standard errors in parentheses, with household clusters

$* * * \mathrm{p}<0.01, * * \mathrm{p}<0.05, * \mathrm{p}<0.1$ 
Table A12: Intergenerational Mobility in Occupational Status, Marginal Effects from Ordered Probit, Sons and Daughters (2013)

\begin{tabular}{|c|c|c|c|c|c|c|}
\hline & None & Elementary & $\begin{array}{l}\text { Skilled } \\
\text { Agricultural }\end{array}$ & $\begin{array}{l}\text { Services \& } \\
\text { Sales }\end{array}$ & $\begin{array}{l}\text { Machine } \\
\text { operator \& } \\
\text { crafts }\end{array}$ & $\begin{array}{l}\text { Managerial } \\
\& \\
\text { Professional }\end{array}$ \\
\hline \multirow[t]{2}{*}{ Elementary } & $0.090 * * *$ & $0.008 * * *$ & $-0.007 * * *$ & $-0.022 * * *$ & $-0.023 * * *$ & $-0.046 * * *$ \\
\hline & $(0.016)$ & $(0.001)$ & $(0.002)$ & $(0.004)$ & $(0.004)$ & $(0.008)$ \\
\hline \multirow[t]{2}{*}{ Skilled Agricultural } & $0.047 * * *$ & $0.006 * * *$ & $-0.003 * * *$ & $-0.011 * * *$ & $-0.013 * * *$ & $-0.027 * * *$ \\
\hline & $(0.011)$ & $(0.001)$ & $(0.001)$ & $(0.003)$ & $(0.003)$ & $(0.006)$ \\
\hline \multirow[t]{2}{*}{ Services \& Sales } & -0.000 & -0.000 & 0.000 & 0.000 & 0.000 & 0.000 \\
\hline & $(0.014)$ & $(0.002)$ & $(0.000)$ & $(0.003)$ & $(0.004)$ & $(0.009)$ \\
\hline \multirow[t]{2}{*}{ Machine operator } & $-0.032 *$ & -0.006 & $0.001 *$ & $0.007^{*}$ & $0.009 *$ & $0.022 *$ \\
\hline & $(0.018)$ & $(0.004)$ & $(0.000)$ & $(0.004)$ & $(0.005)$ & $(0.013)$ \\
\hline \multirow[t]{2}{*}{ Managerial \& Prof. } & $-0.137 * * *$ & $-0.039 * * *$ & $-0.009 * * *$ & $0.019 * * *$ & $0.039 * * *$ & $0.127 * * *$ \\
\hline & $(0.015)$ & $(0.006)$ & $(0.003)$ & $(0.002)$ & $(0.004)$ & (0.019) \\
\hline \multirow[t]{2}{*}{ Age } & $-0.118 * * *$ & $-0.017 * * *$ & $0.005 * * *$ & $0.026 * * *$ & $0.032 * * *$ & $0.073 * * *$ \\
\hline & $(0.026)$ & $(0.004)$ & $(0.001)$ & $(0.006)$ & $(0.007)$ & $(0.016)$ \\
\hline \multirow[t]{2}{*}{ Age squared } & $0.002 * * *$ & $0.000 * * *$ & $-0.000 * * *$ & $-0.000 * * *$ & $-0.001 * * *$ & $-0.001 * * *$ \\
\hline & $(0.000)$ & $(0.000)$ & $(0.000)$ & $(0.000)$ & $(0.000)$ & $(0.000)$ \\
\hline \multirow[t]{2}{*}{ Female } & $0.085 * * *$ & $0.012 * * *$ & $-0.003 * * *$ & $-0.018 * * *$ & $-0.023 * * *$ & $-0.052 * * *$ \\
\hline & $(0.008)$ & $(0.001)$ & $(0.001)$ & $(0.002)$ & $(0.002)$ & $(0.005)$ \\
\hline \multirow[t]{2}{*}{ Two parent $\mathrm{HH}$} & $-0.018 * *$ & $-0.003 * *$ & $0.001 * *$ & $0.004 * *$ & $0.005 * *$ & $0.011 * *$ \\
\hline & $(0.009)$ & $(0.001)$ & $(0.000)$ & $(0.002)$ & $(0.002)$ & $(0.006)$ \\
\hline \multirow[t]{2}{*}{ No. of siblings } & $0.011 * * *$ & $0.002 * * *$ & $-0.000 * * *$ & $-0.002 * * *$ & $-0.003 * * *$ & $-0.007 * * *$ \\
\hline & $(0.002)$ & $(0.000)$ & $(0.000)$ & $(0.000)$ & $(0.001)$ & $(0.001)$ \\
\hline \multirow[t]{2}{*}{ Tigrary } & $-0.047 * * *$ & $-0.008 * *$ & $0.001 * * *$ & $0.010 * * *$ & $0.013 * * *$ & $0.030 * * *$ \\
\hline & $(0.016)$ & $(0.003)$ & $(0.001)$ & $(0.003)$ & $(0.004)$ & $(0.011)$ \\
\hline \multirow[t]{2}{*}{ Afar } & 0.045 & $0.004 * *$ & -0.003 & -0.011 & -0.012 & $-0.023 *$ \\
\hline & $(0.029)$ & $(0.002)$ & $(0.003)$ & $(0.007)$ & $(0.007)$ & $(0.014)$ \\
\hline \multirow[t]{2}{*}{ Amhara } & -0.014 & -0.002 & 0.001 & 0.003 & 0.004 & 0.008 \\
\hline & $(0.013)$ & $(0.002)$ & $(0.001)$ & $(0.003)$ & $(0.003)$ & $(0.008)$ \\
\hline \multirow[t]{2}{*}{ Somalie } & $0.085 * * *$ & $0.006 * * *$ & $-0.008 * *$ & $-0.021 * * *$ & $-0.021 * * *$ & $-0.041 * * *$ \\
\hline & $(0.028)$ & $(0.001)$ & $(0.003)$ & $(0.007)$ & $(0.007)$ & $(0.012)$ \\
\hline \multirow[t]{2}{*}{ Benishangul-Gumuz } & -0.016 & -0.002 & 0.001 & 0.003 & 0.004 & 0.009 \\
\hline & $(0.030)$ & $(0.004)$ & $(0.001)$ & $(0.007)$ & $(0.008)$ & $(0.019)$ \\
\hline \multirow[t]{2}{*}{ SNNPR } & -0.012 & -0.002 & 0.001 & 0.003 & 0.003 & 0.007 \\
\hline & $(0.013)$ & $(0.002)$ & $(0.001)$ & $(0.003)$ & $(0.004)$ & $(0.008)$ \\
\hline \multirow[t]{2}{*}{ Gambela } & $0.064^{*}$ & $0.005 * * *$ & -0.005 & $-0.016^{*}$ & $-0.016^{*}$ & $-0.032 * *$ \\
\hline & $(0.034)$ & $(0.002)$ & $(0.004)$ & $(0.009)$ & $(0.008)$ & $(0.015)$ \\
\hline \multirow[t]{2}{*}{ Harari } & -0.023 & -0.003 & 0.001 & 0.005 & 0.006 & 0.014 \\
\hline & $(0.027)$ & $(0.004)$ & $(0.001)$ & $(0.006)$ & $(0.007)$ & $(0.017)$ \\
\hline \multirow[t]{2}{*}{ Addis Ababa } & $-0.033 * * *$ & $-0.005 * * *$ & $0.001 * *$ & $0.007 * *$ & $0.009 * *$ & $0.021 * * *$ \\
\hline & $(0.013)$ & $(0.002)$ & $(0.001)$ & $(0.003)$ & $(0.004)$ & $(0.008)$ \\
\hline \multirow[t]{2}{*}{ Dire Dawa } & $0.060 * *$ & $0.005 * * *$ & $-0.005^{*}$ & $-0.015 * *$ & $-0.015 * *$ & $-0.030 * *$ \\
\hline & $(0.029)$ & $(0.002)$ & $(0.003)$ & $(0.007)$ & $(0.007)$ & $(0.013)$ \\
\hline $\mathrm{N}$ & 7759 & 7759 & 7759 & 7759 & 7759 & 7759 \\
\hline
\end{tabular}

Robust standard errors in parentheses, with household clusters

$* * * \mathrm{p}<0.01, * * \mathrm{p}<0.05, * \mathrm{p}<0.1$ 
Table A13: Intergenerational Mobility in Occupational Status, Marginal Effects from Ordered Probit, Sons (2013)

\begin{tabular}{|c|c|c|c|c|c|c|}
\hline & None & Elementary & $\begin{array}{l}\text { Skilled } \\
\text { Agricultural }\end{array}$ & $\begin{array}{l}\text { Services \& } \\
\text { Sales }\end{array}$ & $\begin{array}{l}\text { Machine } \\
\text { operator \& } \\
\text { crafts }\end{array}$ & $\begin{array}{l}\text { Managerial } \\
\& \\
\text { Professional }\end{array}$ \\
\hline \multirow[t]{2}{*}{ Elementary } & $0.082 * * *$ & $0.013 * * *$ & $-0.006 * * *$ & $-0.014 * * *$ & $-0.028 * * *$ & $-0.046 * * *$ \\
\hline & $(0.020)$ & $(0.003)$ & $(0.002)$ & $(0.004)$ & $(0.007)$ & $(0.010)$ \\
\hline \multirow[t]{2}{*}{ Skilled Agricultural } & $0.038 * * *$ & $0.007 * * *$ & $-0.002 * *$ & $-0.006 * * *$ & $-0.013 * * *$ & $-0.024 * * *$ \\
\hline & $(0.014)$ & $(0.003)$ & $(0.001)$ & $(0.002)$ & $(0.005)$ & $(0.009)$ \\
\hline \multirow[t]{2}{*}{ Services \& Sales } & -0.009 & -0.002 & 0.000 & 0.001 & 0.003 & 0.007 \\
\hline & $(0.017)$ & $(0.004)$ & $(0.000)$ & $(0.003)$ & $(0.006)$ & $(0.012)$ \\
\hline \multirow[t]{2}{*}{ Machine operator } & $-0.050 * *$ & $-0.013 * *$ & -0.002 & $0.007 * * *$ & $0.018 * *$ & $0.040 * *$ \\
\hline & $(0.021)$ & $(0.006)$ & $(0.002)$ & $(0.002)$ & $(0.008)$ & $(0.018)$ \\
\hline \multirow[t]{2}{*}{ Managerial \& Prof. } & $-0.140 * * *$ & $-0.052 * * *$ & $-0.022 * * *$ & $0.009 * * *$ & $0.049 * * *$ & $0.155^{* * *}$ \\
\hline & $(0.018)$ & $(0.009)$ & $(0.006)$ & $(0.002)$ & $(0.006)$ & $(0.027)$ \\
\hline \multirow[t]{2}{*}{ Age } & $-0.131 * * *$ & $-0.027 * * *$ & 0.002 & $0.019 * * *$ & $0.046^{* * *}$ & $0.092 * * *$ \\
\hline & $(0.033)$ & $(0.007)$ & $(0.001)$ & $(0.005)$ & $(0.011)$ & $(0.023)$ \\
\hline \multirow[t]{2}{*}{ Age squared } & $0.002 * * *$ & $0.000 * * *$ & -0.000 & $-0.000 * * *$ & $-0.001 * * *$ & $-0.001 * * *$ \\
\hline & $(0.001)$ & $(0.000)$ & $(0.000)$ & $(0.000)$ & $(0.000)$ & $(0.000)$ \\
\hline \multirow[t]{2}{*}{ Two parent $\mathrm{HH}$} & 0.001 & 0.000 & -0.000 & -0.000 & -0.000 & -0.000 \\
\hline & $(0.011)$ & $(0.002)$ & $(0.000)$ & $(0.002)$ & $(0.004)$ & $(0.008)$ \\
\hline \multirow[t]{2}{*}{ No. of siblings } & $0.009 * * *$ & $0.002 * * *$ & -0.000 & $-0.001 * * *$ & $-0.003 * * *$ & $-0.006 * * *$ \\
\hline & $(0.003)$ & $(0.001)$ & $(0.000)$ & $(0.000)$ & $(0.001)$ & $(0.002)$ \\
\hline \multirow[t]{2}{*}{ Tigray } & $-0.047 * *$ & $-0.010 * *$ & 0.000 & $0.007 * *$ & $0.017 * *$ & $0.033 * *$ \\
\hline & $(0.019)$ & $(0.005)$ & $(0.001)$ & $(0.003)$ & $(0.007)$ & $(0.014)$ \\
\hline \multirow[t]{2}{*}{ Afar } & 0.034 & 0.005 & -0.002 & -0.006 & -0.012 & -0.019 \\
\hline & $(0.034)$ & $(0.004)$ & $(0.003)$ & $(0.006)$ & $(0.011)$ & $(0.018)$ \\
\hline \multirow[t]{2}{*}{ Amhara } & -0.010 & -0.002 & 0.000 & 0.002 & 0.003 & 0.006 \\
\hline & $(0.016)$ & $(0.003)$ & $(0.001)$ & $(0.003)$ & $(0.006)$ & $(0.010)$ \\
\hline \multirow[t]{2}{*}{ Somalie } & $0.064 *$ & $0.008 * *$ & -0.005 & $-0.011 *$ & $-0.022 *$ & $-0.034 * *$ \\
\hline & $(0.035)$ & $(0.003)$ & $(0.004)$ & $(0.007)$ & $(0.011)$ & $(0.017)$ \\
\hline \multirow[t]{2}{*}{ Benishangul-Gumuz } & -0.013 & -0.002 & 0.000 & 0.002 & 0.004 & 0.008 \\
\hline & $(0.038)$ & $(0.008)$ & $(0.001)$ & $(0.006)$ & $(0.013)$ & $(0.025)$ \\
\hline \multirow[t]{2}{*}{ SNNPR } & -0.018 & -0.004 & 0.001 & 0.003 & 0.006 & 0.012 \\
\hline & $(0.016)$ & $(0.003)$ & $(0.001)$ & $(0.003)$ & $(0.006)$ & $(0.011)$ \\
\hline \multirow[t]{2}{*}{ Gambela } & 0.043 & 0.006 & -0.003 & -0.007 & -0.014 & -0.024 \\
\hline & $(0.047)$ & $(0.006)$ & $(0.005)$ & $(0.008)$ & $(0.016)$ & $(0.024)$ \\
\hline \multirow[t]{2}{*}{ Harari } & 0.020 & 0.003 & -0.001 & -0.003 & -0.007 & -0.012 \\
\hline & $(0.036)$ & $(0.005)$ & $(0.003)$ & $(0.006)$ & $(0.012)$ & $(0.020)$ \\
\hline \multirow[t]{2}{*}{ Addis Ababa } & $-0.051 * * *$ & $-0.011 * * *$ & 0.000 & $0.007 * * *$ & $0.018 * * *$ & $0.036 * * *$ \\
\hline & $(0.016)$ & $(0.004)$ & $(0.001)$ & $(0.002)$ & $(0.006)$ & $(0.011)$ \\
\hline \multirow[t]{2}{*}{ Dire Dawa } & 0.045 & 0.006 & -0.003 & -0.008 & -0.015 & -0.025 \\
\hline & $(0.037)$ & $(0.004)$ & $(0.004)$ & $(0.007)$ & $(0.012)$ & (0.019) \\
\hline $\mathrm{N}$ & 4483 & 4483 & 4483 & 4483 & 4483 & 4483 \\
\hline
\end{tabular}

Robust standard errors in parentheses, with household clusters

$* * * \mathrm{p}<0.01, * * \mathrm{p}<0.05, * \mathrm{p}<0.1$ 
Table A14: Intergenerational Mobility in Occupational Status, Marginal Effects from Ordered Probit, Daughters (2013)

\begin{tabular}{|c|c|c|c|c|c|c|}
\hline & None & Elementary & $\begin{array}{l}\text { Skilled } \\
\text { Agricultural }\end{array}$ & $\begin{array}{l}\text { Services \& } \\
\text { Sales }\end{array}$ & $\begin{array}{l}\text { Machine } \\
\text { operator \& } \\
\text { crafts }\end{array}$ & $\begin{array}{l}\text { Managerial } \\
\& \\
\text { Professional }\end{array}$ \\
\hline \multirow[t]{2}{*}{ Elementary } & $0.106 * * *$ & 0.002 & $-0.007 * * *$ & $-0.038 * * *$ & $-0.015^{* * *}$ & $-0.048 * * *$ \\
\hline & $(0.027)$ & $(0.002)$ & $(0.002)$ & $(0.010)$ & $(0.004)$ & $(0.011)$ \\
\hline \multirow[t]{2}{*}{ Skilled Agricultural } & $0.050 * * *$ & $0.002 * *$ & $-0.003 * * *$ & $-0.017 * * *$ & $-0.007 * * *$ & $-0.025 * * *$ \\
\hline & $(0.019)$ & $(0.001)$ & $(0.001)$ & $(0.007)$ & $(0.003)$ & $(0.010)$ \\
\hline \multirow[t]{2}{*}{ Services \& Sales } & 0.016 & 0.001 & -0.001 & -0.006 & -0.002 & -0.009 \\
\hline & $(0.024)$ & $(0.002)$ & $(0.001)$ & $(0.008)$ & $(0.003)$ & $(0.013)$ \\
\hline \multirow[t]{2}{*}{ Machine operator } & -0.000 & -0.000 & 0.000 & 0.000 & 0.000 & 0.000 \\
\hline & $(0.032)$ & $(0.003)$ & $(0.001)$ & $(0.011)$ & $(0.005)$ & $(0.018)$ \\
\hline \multirow[t]{2}{*}{ Managerial \& Prof. } & $-0.128 * * *$ & $-0.024 * * *$ & -0.000 & $0.035 * * *$ & $0.020 * * *$ & $0.097 * * *$ \\
\hline & $(0.027)$ & $(0.007)$ & $(0.002)$ & $(0.006)$ & $(0.005)$ & $(0.025)$ \\
\hline \multirow[t]{2}{*}{ Age } & $-0.091 * *$ & $-0.006 * *$ & $0.004 * *$ & $0.030 * *$ & $0.013 * *$ & $0.049 * *$ \\
\hline & $(0.043)$ & $(0.003)$ & $(0.002)$ & $(0.014)$ & $(0.006)$ & $(0.023)$ \\
\hline \multirow[t]{2}{*}{ Age squared } & $0.002 * *$ & $0.000 * *$ & $-0.000 * *$ & $-0.001 * *$ & $-0.000 * *$ & $-0.001 * *$ \\
\hline & $(0.001)$ & $(0.000)$ & $(0.000)$ & $(0.000)$ & $(0.000)$ & $(0.000)$ \\
\hline \multirow[t]{2}{*}{ Two parent HH } & $-0.043^{* * *}$ & $-0.003 * * *$ & $0.002 * * *$ & $0.014 * * *$ & $0.006 * * *$ & $0.023 * * *$ \\
\hline & $(0.015)$ & $(0.001)$ & $(0.001)$ & $(0.005)$ & $(0.002)$ & $(0.008)$ \\
\hline \multirow[t]{2}{*}{ No. of siblings } & $0.013 * * *$ & $0.001 * * *$ & $-0.001 * * *$ & $-0.004 * * *$ & $-0.002 * * *$ & $-0.007 * * *$ \\
\hline & $(0.004)$ & $(0.000)$ & $(0.000)$ & $(0.001)$ & $(0.001)$ & $(0.002)$ \\
\hline \multirow[t]{2}{*}{ Tigray } & -0.044 & -0.004 & $0.002 *$ & 0.014 & 0.007 & 0.026 \\
\hline & $(0.029)$ & $(0.003)$ & $(0.001)$ & $(0.009)$ & $(0.004)$ & $(0.018)$ \\
\hline \multirow[t]{2}{*}{ Afar } & 0.060 & 0.002 & -0.004 & -0.021 & -0.008 & -0.028 \\
\hline & $(0.052)$ & $(0.001)$ & $(0.004)$ & $(0.019)$ & $(0.007)$ & $(0.023)$ \\
\hline \multirow[t]{2}{*}{ Amhara } & -0.018 & -0.001 & 0.001 & 0.006 & 0.003 & 0.010 \\
\hline & $(0.022)$ & $(0.002)$ & $(0.001)$ & $(0.007)$ & $(0.003)$ & $(0.012)$ \\
\hline \multirow[t]{2}{*}{ Somalie } & $0.113 * *$ & -0.000 & $-0.008 * *$ & $-0.040 * *$ & $-0.015 * *$ & $-0.049 * * *$ \\
\hline & $(0.046)$ & $(0.003)$ & $(0.004)$ & $(0.017)$ & $(0.006)$ & $(0.017)$ \\
\hline \multirow[t]{2}{*}{ Benishangul-Gumuz } & -0.020 & -0.002 & 0.001 & 0.007 & 0.003 & 0.011 \\
\hline & $(0.048)$ & $(0.004)$ & $(0.002)$ & $(0.016)$ & $(0.007)$ & $(0.028)$ \\
\hline \multirow[t]{2}{*}{ SNNPR } & 0.001 & 0.000 & -0.000 & -0.000 & -0.000 & -0.000 \\
\hline & $(0.023)$ & $(0.002)$ & $(0.001)$ & $(0.008)$ & $(0.003)$ & $(0.013)$ \\
\hline \multirow[t]{2}{*}{ Gambela } & $0.091^{*}$ & 0.001 & -0.006 & $-0.032 *$ & $-0.012 *$ & $-0.041 * *$ \\
\hline & $(0.049)$ & $(0.002)$ & $(0.004)$ & $(0.018)$ & $(0.006)$ & (0.019) \\
\hline \multirow[t]{2}{*}{ Harari } & $-0.071 *$ & -0.008 & $0.002 * *$ & $0.022 *$ & $0.011 *$ & 0.044 \\
\hline & $(0.042)$ & $(0.007)$ & $(0.001)$ & $(0.012)$ & $(0.006)$ & $(0.029)$ \\
\hline \multirow[t]{2}{*}{ Addis Ababa } & 0.001 & 0.000 & -0.000 & -0.000 & -0.000 & -0.000 \\
\hline & $(0.022)$ & $(0.001)$ & $(0.001)$ & $(0.008)$ & $(0.003)$ & $(0.012)$ \\
\hline \multirow[t]{2}{*}{ Dire Dawa } & $0.085^{*}$ & 0.001 & -0.006 & $-0.030 *$ & $-0.012 *$ & $-0.039 * *$ \\
\hline & $(0.045)$ & $(0.002)$ & $(0.004)$ & $(0.016)$ & $(0.006)$ & $(0.018)$ \\
\hline $\mathrm{N}$ & 3276 & 3276 & 3276 & 3276 & 3276 & 3276 \\
\hline
\end{tabular}

Robust standard errors in parentheses, with household clusters

$* * * \mathrm{p}<0.01, * * \mathrm{p}<0.05, * \mathrm{p}<0.1$ 